\title{
Bioconversion of Crude Glycerol to Hydrogen and Methane in Three-Stage Horizontal Anaerobic Fixed- Bed Reactors (HARFB)
}

\section{Luan Vieira Adames ( $\square$ Ivadames@gmail.com )}

UNESP IQAR: Universidade Estadual Paulista Julio de Mesquita Filho Instituto de Quimica https://orcid.org/0000-0002-3912-687X

\section{Ana Paula Jacobus}

UNESP: Universidade Estadual Paulista Julio de Mesquita Filho

\section{Isabel Sakamoto}

USP EESC: Universidade de Sao Paulo Escola de Engenharia de Sao Carlos

\section{Carolina Zampol Lázaro}

University of Montreal: Universite de Montreal

\section{Lorena Oliveira Pires}

UNESP IQAR: Universidade Estadual Paulista Julio de Mesquita Filho Instituto de Quimica

\section{Sandra Imaculada Maintinguer}

UNESP: Universidade Estadual Paulista Julio de Mesquita Filho

\section{Research Article}

Keywords: Biodiesel, domestic sewage, bioenergy, co-digestion, PCR-DGGE.

Posted Date: November 16th, 2021

DOl: https://doi.org/10.21203/rs.3.rs-1051332/v1

License: (c) (i) This work is licensed under a Creative Commons Attribution 4.0 International License. Read Full License 


\section{Abstract}

The anaerobic conversion of residual glycerol from biodiesel production is an excellent option for producing clean energy at a low cost. Crude glycerol (CG) is an excellent carbon source for microorganisms in Anaerobic Digestion (AD) process; however, it is a nutrient-limited waste. On the other hand, domestic Sewage (DS) is wastewater containing macronutrients, such as nitrogen and phosphorus. Therefore, feeding bioreactors with a blend of both wastes is an exciting approach. The objective of this study was to operate a system consisting of three horizontal anaerobic series reactors (HARFB) with fixed bed (R1, R2, and R3), fed with a mixture of crude glycerol and domestic sewage to evaluate the start-up strategy and best organic loading rate (OLR) to improve biogas production $\left(\mathrm{H}_{2} \mathrm{e} \mathrm{CH}_{4}\right)$ as well as to analyze the dynamic changes in the anaerobic microbial consortium during the operation of the HARFB. The highest hydrogen generation was 10.3 moles $\mathrm{H}_{2}\left(\mathrm{~m}^{3} \mathrm{~d}^{-1}\right)$ in reactor $\mathrm{R} 1$, and the highest methane yield was 312.0 and $283.9 \mathrm{~L} \mathrm{CH}_{4}\left(\mathrm{~m}^{3} \mathrm{~d}^{-1}\right)$ in R2 and R3, respectively. The three-stage system showed high efficiency in removing crude glycerol and Chemical Oxygen Demand (COD), with consumptions of $99.9 \%$. In addition, there was a change in the relative abundance of microorganisms amongst R1, R2, and R3 and a considerable decrease in the diversity index in the fermentation reactor (R1). The results have shown the potential of applying HARFB reactors for energy recovery and alternative waste disposal.

\section{Introduction}

Biodiesel production has been grown worldwide thanks to incentive policies for the expansion of renewable energy generation. Each ton of biodiesel produced through triglycerides transesterification generates around $100 \mathrm{~kg}$ of crude glycerol, its main by-product [1]. Crude glycerol contains impurities, such as alcohols, fatty acids, esters, alkalis in the form of soaps, alkali hydroxides, and heavy metals [2, 3]. This waste is widely used in the pharmaceutical, food, and cosmetic industry; however, its purification is costly, being a drawback especially for small and medium manufacturers [4]. As a result, disposal alternatives have been studied. Glycerol's high calorific capacity, long-term stability, and biodegradability make it a good candidate for being used as substrate in Anaerobic Digestion (AD) aiming hydrogen and methane production [5-9].

The AD is a very complex process involving the synergism of microorganisms, including those from Bacteria and Archaea Domain, which interact sequentially and simultaneously to convert the complex organic matter into simpler compounds, i.e., volatile organic acids, alcohols, hydrogen, and methane [10].

Crude glycerol is an excellent carbon source for microorganisms; however, it is a nutrient-limited waste. On the other hand, domestic Sewage (DS)s wastewater containing macronutrients, such as nitrogen and phosphorus [11]. Therefore, feeding bioreactors with a blend of both wastes is an exciting approach. Furthermore, the water from DS can simultaneously dilute toxic compounds in crude glycerol and provide macronutrients $[3,12]$. 
Consequently, the knowledge of temporal and spatially microbiological composition inside bioreactors against different operational conditions (i.e., temperature, $\mathrm{pH}$, hydraulic retention time, organic loading rate) has become a key to understand how those affect microbial diversity, therefore, culminating in different process efficiency [13].

Active microorganisms can act as indicators capable of reflecting subtle changes in the operation of biological reactors long before changes in the levels of organic matter can be observed. Although AD has been considered a well-established technology, the microbial diversity and the interspecies relations seem to vary widely depending on the type of residue/inoculum used, operational conditions, and reactors configurations $[14,15]$. Therefore, molecular genetic techniques such as denaturation gradient gel electrophoresis (PCR-DGGE) is a helpful tool to rapidly detect changes in the microbial community [14, $16,17]$. Additionally, DNA-sequencing technologies for identifying microbial species in bioreactors are valuable tools for understanding, controlling, and improving the bioreactor performance of biogas production systems. That being said, the aim of the present study was to evaluate: (1) the consumption of crude glycerol co-digested with Domestic Sewage, (2) the production of hydrogen and methane, and (3) the microbial diversity throughout the operational period in three horizontal sequential anaerobic fixed bed reactors (HARFB).

\section{Material And Methods}

\subsection{Inoculum and Inoculation Strategies}

An up-flow anaerobic sludge blanket (UASB) granular methanogenic sludge treating slaughterhouse wastewater, with and without pre-treatment, was used as inoculum. First, fermentative Reactor (R1) was inoculated with acid pre-treated inoculum ( $\mathrm{pH} 3.0$ for $24 \mathrm{~h}$ at $37^{\circ} \mathrm{C}$ ) as per Rossi et al. [18]. After that, the sludge's $\mathrm{pH}$ was adjusted to 5.5 , and it was inserted in R1 along with the support material. Then, for the Methanogenic Reactors (R2 and R3), the sludge without pre-treatment, named inoculum in natura, was mixed with the support material and used to fill the reactors.

\subsection{Substrates}

Crude glycerol (CG), generated from the transesterification of vegetal oils and animal fat for biodiesel production, was provided by Biobrotas located in Brotas, SP/Brazil. The feedstock was stored in dark polyethylene gallons kept at room temperature until its usage. Glycerol Physico-chemical characteristics were: COD $1.92 \mathrm{~kg} \mathrm{~L}^{-1}, 80.6 \%$ glycerol content, $\mathrm{pH} 4.35,5.3 \%$ of chlorines, $11.4 \%$ humidity, $5.1 \%$ ashes and $2.84 \%$ non-glycerol organic matter.

Domestic Sewage (DS) was provided by BRK Ambiental Company, the operator of a wastewater treatment plant located in Rio Claro (SP-Brazil). The DS, located after the preliminary treatment phase (coarse solid removal), was collected weekly and stored in dark polyethylene gallons kept at room temperature. Its average composition was as follows: $350 \mathrm{mg} \mathrm{COD} \mathrm{L}^{-1}( \pm 188), 150 \mathrm{mg} \mathrm{TS} \mathrm{L}^{-1}( \pm 73), \mathrm{pH}$ $7.0( \pm 0.3)$. 


\subsection{Experimental set-up and operating conditions}

Three horizontal reactors built as per Zaiat et al. [19] were operated sequentially in this study. They were made of 2 meters long PVC tubes with entry and exit ports (Influent and Effluent) (Fig. 1). The reactor's diameters were $5 \mathrm{~cm}, 10 \mathrm{~cm}$, and $15 \mathrm{~cm}$ for R1, R2, and R3, respectively, to favor shorter fermentation times and longer methanogenesis. The aim of the first reactor (R1) was the fermentation of organic matter into organic acids and hydrogen, being the biogas collected and the liquid by-products used as the carbon source for the two subsequential bioreactors (R2 and R3). The effluent of R1 was used as the substrate for R2 without any pre-treatment as the system was operated sequentially. The third reactor was provided to consume the volatile fatty acids produced in the first two reactors. The main aim was to remove the remaining organic matter transforming it into $\mathrm{CH}_{4}$ and $\mathrm{CO}_{2}$.

The support material used to allow microorganisms aggregation increasing biomass concentration inside bioreactors was a corrugated conduit ( $2 \mathrm{~cm}$ diameter $\times 2 \mathrm{~cm}$ long). The reactors were kept at room temperature without any temperature control systems for 250 days. After this period, an external temperature controlling system, consisting of silicone tubes filled with water kept at $37^{\circ} \mathrm{C}$ and involving the bioreactors, was installed.

This study was performed in 2 different phases: Start-up and Phase 1. During the Start-up Phase, the system was fed with DS $\left(6.33 \mathrm{ml} \mathrm{min}^{-1}\right.$ and $\left.350 \mathrm{mg} \mathrm{COD} \mathrm{L}^{-1}\right)$ for 20 days. After this period, the influent consisted of a blend of DS and CG $(1 \%, \mathrm{v} / \mathrm{v})$, increasing the influent COD concentration to an average of $10.6 \mathrm{~g} \mathrm{~L}^{-1}( \pm 4.2)$ for 200 days. In this phase, the affluent were fed at $2.64 \mathrm{ml} \mathrm{min}^{-1}$, increasing the HRT from 0.5 to 1 day in R1, 2.1 to 4.2 days in R2, and 4 to 8 days. Table 1 summarizes operational conditions (influent and effluent COD, OLR, and HRT) during Start-up and Phase 1. In addition, $\mathrm{NaHCO}_{3}\left(1 \mathrm{~g} \mathrm{~L}^{-1}\right.$ per liter of the reactor) was added to the reactor's influent during Start-up and Phase 1. Throughout the experiment, the influent consisting of crude glycerol (CG) $(1 \% \mathrm{v} / \mathrm{v})$ and DS $(99 \% \mathrm{v} / \mathrm{v})$ was prepared and kept refrigerated at $4^{\circ} \mathrm{C}$. 
Table 1

- Mean values $( \pm S D, n=$ number of samples) of COD, organic loading rate (OLR), and hydraulic retention time (HRT) of the influent and effluents of reactors R1, R2, and R3 during the start-up and Phase 1

\begin{tabular}{|c|c|c|c|c|c|c|}
\hline & \multicolumn{2}{|l|}{$\begin{array}{l}\text { COD } \\
\left(g ~ L^{-1}\right)\end{array}$} & \multicolumn{2}{|c|}{$\begin{array}{l}\text { OLR } \\
\left(\mathrm{Kg} \operatorname{COD}\left(\mathrm{m}^{3} \mathrm{~d}\right)^{-1}\right)\end{array}$} & \multicolumn{2}{|l|}{$\begin{array}{l}\text { HRT } \\
\text { (days) }\end{array}$} \\
\hline & *Start-up & **Phase 1 & *Start-up & **Phase 1 & *Start-up & **Phase 1 \\
\hline Influent & $\begin{array}{l}13.0 \\
( \pm 1.3)\end{array}$ & $\begin{array}{l}18.1 \\
( \pm 2.1)\end{array}$ & - & - & - & - \\
\hline $\begin{array}{l}\text { R1 } \\
\text { (Effluent) }\end{array}$ & $\begin{array}{l}10.7 \\
( \pm 1.2)\end{array}$ & $\begin{array}{l}15.6 \\
( \pm 2.7)\end{array}$ & $\begin{array}{l}25.4 \\
( \pm 10.2)\end{array}$ & $\begin{array}{l}13.1 \\
( \pm 1.3)\end{array}$ & 0.5 & 1.0 \\
\hline $\begin{array}{l}\text { R2 } \\
\text { (Effluent) }\end{array}$ & $\begin{array}{l}8.9 \\
( \pm 1.9)\end{array}$ & $\begin{array}{l}12.0 \\
( \pm 6.1)\end{array}$ & $\begin{array}{l}6.2 \\
( \pm 2.5)\end{array}$ & $\begin{array}{l}3.1 \\
( \pm 0.3)\end{array}$ & 2.1 & 4.2 \\
\hline $\begin{array}{l}\text { R3 } \\
\text { (Effluent) }\end{array}$ & $\begin{array}{l}0.8 \\
( \pm 0.8)\end{array}$ & $\begin{array}{l}0.3 \\
( \pm 0.1)\end{array}$ & $\begin{array}{l}3.2 \\
( \pm 1.3)\end{array}$ & $\begin{array}{l}1.6 \\
( \pm 0.2)\end{array}$ & 4.02 & 8.04 \\
\hline
\end{tabular}

\subsection{Physico-chemical and Chromatographic Analysis}

The influent and effluent of reactors R1, R2, and R3 were analyzed weekly for $\mathrm{pH}$ [20], alkalinity [21], Volatile Fatty Acids (VFA) [22], Chemical Oxygen Demand (COD) [20].

Total biogas volumetric production was measured by water displacement [23] and real-time biogas production was recorded using an adapted Arduino microcontroller [24]. Biogas composition was performed by gas chromatography using a Shimadzu GC-2014, equipped with column1010 PLOT (30 m x $0.53 \mathrm{~mm}$ ), thermal conductivity detector (TCD), and using Argon as a gas carrier. Injector and detector temperature were set as $220^{\circ} \mathrm{C} \mathrm{e} 230^{\circ} \mathrm{C}$, respectively. Column temperature ramp was: $120^{\circ} \mathrm{C}(1 \mathrm{~min})$, $40^{\circ} \mathrm{C} / \mathrm{min}$ up to $200^{\circ} \mathrm{C}(3 \mathrm{~min}), 50^{\circ} \mathrm{C} / \mathrm{min}$ up to $230^{\circ} \mathrm{C}(0,5 \mathrm{~min})$ [25].

\subsection{Microbial Diversity Analysis}

Sludge samples taken from R1, R2, and R3 were analyzed by Scanning Electron Microscope (SEM). The samples were fixed in hexamethyldisilazane following the methodology described by Nation [26].

\subsubsection{DNA Sequencing}

Samples from each reactor collected at the beginning of Phase 1 were named INOC. At the end of the same phase, after 260 days of operation, samples taken from the three sampling points (P1, P2, and P3) 
of each reactor (Fig. 1) were homogenized, and this composite sample was used for analysis.

DNA extraction was carried out by the phenol-chloroform modified method [27]. Extracted DNA integrity was verified by a 260/280 ratio using an ND-2000 spectrophotometer (Nanodrop Inc., Wilmington, DEA). DNA was dried out at room temperature for 24 hours and then stored at $-20^{\circ} \mathrm{C}$ until its analysis at GenONE (Rio de Janeiro-RJ, Brazil) using the NGS Illumina MiSeq platform.

\subsubsection{Library Preparation for NGS}

The 16S rRNA / 18SrRNA / ITS regions (16SV4 / 16SV3 / 16SV3-V4 / 16SV4-V5, 18S V4 / 18S V9, ITS1 / ITS2, Arco V4) were amplified using specific primers (16S V4: 515F-806R, 18S V4: 528F-706R, 18S V9: 1380F-1510R. PCR reactions were performed using Phusion ${ }^{\circledR}$ High-Fidelity PCR Master Mix (New England Biolabs).

PCR products were mixed in equal proportional densities and purified using Qiagen Gel Extraction Kit (Qiagen, Germany). Genomic libraries were generated with NEBNext ${ }^{\circledR}$ UltraTM DNA Library Prep Kit and quantified using Qubit e Q-PCR for Illumina sequencing platform.

Paired-end reads were merged using FLASH Algorithm (V1.2.7, http://ccb.jhu.edu/software/FLASH/) [28], and raw sequences were filtered using Qiime (V1.7.0, http://qiime.org/scripts/split_libraries_fastq.html) [29] to obtain high-quality data for further analysis [30]. The filtered sequences were then compared to the ones deposited in Genome OnLine Database - GOLD (http://drive5.com/uchime/uchime_download.html) using UCHIME Algorithm (http://www.drive5.com/usearch/manual/uchime_algo.html ) [31] and chimeric sequences and noise (https://drive5.com/usearch/manual/chimeras.html) were then removed [32]. Then, sequences with a length at least equal to or higher than $403 \mathrm{bp}$ and a quality score Q30 equal to or higher than $92 \%$ (sequence error rate is less than $0.1 \%$ ).

Sequences were deposited in NCBI genetic sequence database, Project name PRJNA531496, Bioproject PRJNA531496, Inoculum: Biosample SAMN15438363 (SRA: SRR12192782); R1: Biosample SAMN15438259 (SRA: SRR12192195); R2: Biosample SAMN15438265 (SRA: SRR12192464); R3: Biosample SAMN15438362 (SRA: SRR12192644).

\subsubsection{PCR-DGGE (Denaturing Gradient Gel Electrophoresis) analysis}

Biomass samples taken from 3 sampling points (P1, P2, and P3) from reactors 1, 2, and 3 (Fig. 1) at the end of Phase 1 ( $260^{\circ}$ day) were analyzed individually by DGGE. Table 2 describes the nomenclature used for each reactor, sampling point, and microbial Domain analyzed to facilitate results presentation and its discussion. 
Table 2

- Sampling nomenclature according to the reactor sampling point and microbial Domain in the HARFB

\begin{tabular}{|c|c|c|c|c|c|c|c|}
\hline & & \multicolumn{6}{|c|}{ Domain } \\
\hline & & \multicolumn{3}{|c|}{ Bacteria } & \multicolumn{3}{|c|}{ Archaea } \\
\hline & & \multicolumn{6}{|l|}{ Reactor } \\
\hline & & R1 & R2 & R3 & R1 & $\mathrm{R} 2$ & R3 \\
\hline \multirow[t]{3}{*}{ Sampling point } & Initial & R1P1b & R2P1b & R3P1b & R1P1a & $\mathrm{R} 2 \mathrm{P} 1 \mathrm{a}$ & R3P1a \\
\hline & Central & $\mathrm{R} 1 \mathrm{P} 2 \mathrm{~b}$ & R2P2b & R3P2b & R1P2a & $\mathrm{R} 2 \mathrm{P} 2 \mathrm{a}$ & R3P2a \\
\hline & Final & R1P3b & R2P3b & R3P3b & R1P3a & R2P3a & R3P3a \\
\hline Inoculum & & INOCb & & & INOCa & & \\
\hline
\end{tabular}

The 16S rDNA sequences were amplified by PCR using the primer 968FGC - 1401R for Bacteria Domain [33] and primer 1100FGC - 1400R for Archaea Domain [34]. The PCR cycle was as follows: initial denaturation $95^{\circ} \mathrm{C}$ for $7 \mathrm{~min}$, denaturation phase $94^{\circ} \mathrm{C}$ for $0.45 \mathrm{~min}$, annealing at $56^{\circ} \mathrm{C}$ for $0.45 \mathrm{~min}$, extension at $72^{\circ} \mathrm{C}$ for $1.0 \mathrm{~min}$, final extension at $72^{\circ} \mathrm{C}$ for $10 \mathrm{~min}$ and $4^{\circ} \mathrm{C}$ for $35 \mathrm{cycles}$ for Bacteria domain and Archaea: initial denaturation $94^{\circ} \mathrm{C}$ for $5 \mathrm{~min}$, denaturation phase $94^{\circ} \mathrm{C}$ for $1 \mathrm{~min}$, annealing at $55^{\circ} \mathrm{C}$ for $1 \mathrm{~min}$, extension at $72^{\circ} \mathrm{C}$ for $1.0 \mathrm{~min}$, final extension at $72^{\circ} \mathrm{C}$ for $7 \mathrm{~min}$ and $4^{\circ} \mathrm{C}$ for $35 \mathrm{cycles}$ [35].

PCR-amplified fragments were separated by denaturing gradient gel electrophoresis (DGGE) prepared and run using TAE 1X solution (Buffer Tris-Acetate - Tris 40mM, Acetic Acid 20mM, EDTA 1mM) at $75 \mathrm{~V}$ and $65^{\circ} \mathrm{C}$ for $16 \mathrm{~h}$ in polyacrylamide gel with denaturant gradient ranging from 45 to $65 \%$. The gel was soaked in Fluorescent dye DiamondTM Nucleic Acid Dye (Promega) (1:10,000) for $20 \mathrm{~min}$, and gel band patterns were observed using Eagle Eye TMIII (Stratagene) with UV at $254 \mathrm{~nm}$, connected to a computer and analyzed using Eagle Sight software (L.PixTouch - Loccus Biotechnology).

Band-based Jaccard similarity coefficient was used for dendrogram construction using BioNumerics software (Applied Biomath, Belgic). Shannon-Wiener diversity index was calculated based on gel band intensities, and pick height was analyzed accordingly to densitometric curves and Eq. (1).

The Shannon-Wiener diversity indices were calculated based on the intensities of the bands in the gel. Peak heights were assessed on densitometric curves, according to Eq. (1).

$$
H=-\sum\left(P_{i} \ln \left(P_{i}\right)\right)
$$

where $H$ is Shannon's diversity index, and $P_{i}$ is the proportion of each species in the sample $\left(P_{i}=n_{i} / N\right.$, where $\mathrm{n}_{\mathrm{i}}$ is the height of an individual peak and $\mathrm{N}$ is the sum of all peak heights). 


\section{Results And Discussion}

\subsection{First Stage - Fermentative Reactor (R1)}

As expected, there was no methane generation in the R1, showing the sludge pre-treatment effectiveness. This type of pre-treatment has greater applicability in pilot-scale reactors and stands out compared to other methods. Rossi et al. [18] evaluated five different pre-treatments and obtained better results using the acid pre-treated mixed bacterial cultures, reaching $64.4 \mathrm{~mL} \mathrm{H}_{2} \mathrm{~g}^{-1}$ of dry grass. Vasconcelos et al. [36] used non-pretreated inoculum for $\mathrm{H}_{2}$ production, and the strategy used to avoid $\mathrm{CH}_{4}$ generation was the increase of OLR to $54.5 \mathrm{Kg} \operatorname{COD}\left(\mathrm{m}^{3} . \mathrm{d}^{-1}\right)$ at HRT 3.5 days.

Biogas production was observed after 89 days of the system's start-up, composed of $1 \% \mathrm{H}_{2}$ and $99 \% \mathrm{CO}_{2}$. Throughout the process, the percentage of hydrogen in the biogas increased progressively. After 160 days, it reached $60 \% \mathrm{H}_{2}$, and the maximum measured was $81 \%$ of $\mathrm{H}_{2}$ (in 211 days). Rivero et al. [2] evaluated the hydrogen production in semi-continuous CSTR fed with a mix of sewage sludge and crude glycerol and obtained the lowest percentages $\left(24-27 \% \mathrm{H}_{2}\right)$ even after reducing the OLR (from 15 to $7.8 \mathrm{~kg}$ $\left.\operatorname{COD}\left(\mathrm{m}^{3} \cdot \mathrm{d}\right)^{-1}\right)$. Higher hydrogen percentages in the biogas composition could be attributed to the system configuration - plug flow reactor model - which allowed the nucleation of the anaerobic microorganisms. During the start-up phase and acclimatization of the microorganisms, the OLR was reduced from $25.4 \mathrm{~kg}$ $\operatorname{COD}\left(\mathrm{m}^{3} \mathrm{~d}\right)^{-1}$ to $13 \mathrm{~kg} \mathrm{COD}\left(\mathrm{m}^{3} \mathrm{~d}\right)^{-1}$, and it seems to have favored the hydrogen and organic acids production (Fig. 2) considerably.

In phase 1, there were higher hydrogen production yields, with daily values of $0.42 \mathrm{~mol} \mathrm{H}_{2} \mathrm{~mol}^{-1}$ glycerol. Vasconcelos et al. [36] evaluated the production of hydrogen in a UASB reactor and obtained less than $0.1 \mathrm{~mol} \mathrm{H}_{2} \mathrm{~mol}^{-1}$ glycerol but applied a much higher OLR $\left(54.5 \mathrm{~kg} \mathrm{COD}\left(\mathrm{m}^{3} . \mathrm{d}\right)^{-1}\right)$. By the results shown in the present study and the ones reported by Vasconcelos et al. [36] who applied a higher OLR, it seems this parameter plays an essential role in the process. Jiraprasertwong et al. [37] evaluated the biogas production using UASB reactors in series and observed a drop in the biogas production when applying OLRs higher than $20.0 \mathrm{Kg} \operatorname{COD}\left(\mathrm{m}^{3} \mathrm{~d}\right)^{-1}$, and this is most likely due to the inhibitory concentration of organic acids.

In terms of hydrogen yield, the values obtained in the present study $(0.138 \pm 0.103$ phase 1$)$ have not achieved the theoretical yield. It is most likely due to the use of carbon sources for cellular growth and the occurrence of different metabolic pathways. In the oxidative route, two moles of $\mathrm{H}_{2}$ can be produced from the oxidation of $1 \mathrm{~mol}$ of glycerol which is first converted into pyruvate, then acetyl-in CoA and formiate, which is then cleaved into $\mathrm{H}_{2}$ and $\mathrm{CO}_{2}$. Nevertheless, the oxidation of acetyl-CoA into ethanol, acetate, and butyrate will not culminate with $\mathrm{H}_{2}$ generation. The same occurs when pyruvate is oxidized into lactic acid [38,39]. A common glycerol by-product is 1,3-propanediol (1,3PD); when glycerol is metabolized via this pathway, there is no $\mathrm{H}_{2}$ production. 
The hydrogen production yields verified were lower than the yields reported by Selembo et al. [40] and Ngo et al. [41] which were 0.69 a $1.12 \mathrm{~mol} \mathrm{H}_{2} \mathrm{~mol}^{-1}$ glycerol, respectively, using pure cultures of Enterobacter aerogenes in anaerobic batch reactors; however, it seems to be laborious avoiding culture contamination when scaling up the process for waste treatment.

An increase in the volatile fatty acids production was observed when the HRT has increased (Fig. 3). The VFA was $2675 \mathrm{mg} \mathrm{L}^{-1}$ (average of $\mathrm{n}$ samples $14 \pm$ SD 644). Jiraprasertwong et al. [37] applying OLR and HRT of $5 \mathrm{Kg}$ COD $\left(\mathrm{m}^{3} \mathrm{~d}\right)^{-1}$ and 10 days, respectively, observed $25000 \mathrm{mg} \mathrm{L}^{-1}$ de VFA, and this value dropped to $10000 \mathrm{mg} \mathrm{VFA} \mathrm{L}^{-1}$ with OLR increasing $\left(10 \mathrm{Kg} \mathrm{COD}\left(\mathrm{m}^{3} \mathrm{~d}\right)^{-1}\right.$. In the present study, using a lower TDH (0.5 days), during the start-up phase, it was produced 1096 VFA mg L ${ }^{-1}$ with a higher OLR $\left(25.4 \mathrm{Kg} \mathrm{COD}\left(\mathrm{m}^{3} \mathrm{~d}\right)^{-1}\right)$, attesting the potential of crude glycerol as a substrate for microorganisms in a HARFB.

The domestic sewage, used with crude glycerol as a substrate for the present study, cannot supply the alkalinity to keep the reactor's $\mathrm{pH}$ stable/controlled. During the start-up phase, no external alkalinity source was added into the substrate blend, and, for this reason, it was observed a pH fluctuation either in the influent and effluent (Fig. 3B). Based on these results, for phase 1, the substrate was supplemented with $1 \mathrm{~g} \mathrm{~L}^{-1} \mathrm{NaHCO}_{3}$, and the $\mathrm{pH}$ was stable $(4.89 \pm 0,40)$ for about 10 days. After this period, a drop in $\mathrm{pH}$ values was observed an increase in the VFA production. (Fig. 3B). Since the substrate was prepared using a blend of residues with variable characteristics, such as the $\mathrm{pH}$, this was expected. The conditions of each biodiesel plant could affect the crude glycerol characteristics, such as pH range. Veras et al. [42] used crude glycerol with $\mathrm{pH} 10.4$ in a UASB reactor and did not observe any excessive acidification with final $\mathrm{pH}$ at around 6.0. In the present study, the crude glycerol had a pH of 4.5, and this value was, on average, 6.3 and 7.2 for the start-up and phase 1, respectively, after its mixture with domestic sewage (Fig. $3 \mathrm{~A}$ and $\mathrm{B}$ ).

\subsection{Second Stage: Methanogenesis Reactor (R2)}

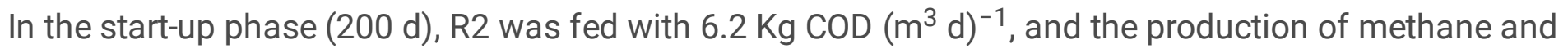
carbon dioxide during this time was $35 \% \mathrm{CH}_{4}$ and $65 \% \mathrm{CO}_{2}$. Followed by the OLR decreasing on Phase 1 , an increase in methane generation and, this value reached $312 \mathrm{~L} \mathrm{CH}_{4}\left(\mathrm{~m}^{3} \mathrm{~d}\right)^{-1}$ (Fig. 4). The percentage of $\mathrm{CH}_{4}$ reached its maximum value at $200^{\circ}$ day $\left(57 \%\right.$ and $\left.43 \% \mathrm{CO}_{2}\right)$.

The increase in the VFA production in the R1 reactor, which was used as an affluent for R2 without any pre-treatment, negatively affected the methane production in R2. The accumulation of VFA likely caused a pH drop, and for this reason, supplementation with $1 \mathrm{~g} \mathrm{NaHCO}_{3}$ (L.d $)^{-1}$ was needed (Fig. 3). As a result, hydrogen was not detected in the biogas produced in R2. It is possible that, if produced, $\mathrm{H}_{2}$ was consumed by hydrogenotrophic methanogenic archaea. The total VFA in the influent of R2 was 1,096 mg $\mathrm{L}^{-1}( \pm 650)$ and $2,675 \mathrm{mg} \mathrm{L}^{-1}( \pm 644)$ during start-up and phase 1 , respectively. The VFA was $2,388 \mathrm{mg}$ $\mathrm{L}^{-1}( \pm 1588)$ and $3,885 \mathrm{mg} \mathrm{L}^{-1}( \pm 867)$ for the phases as mentioned above, respectively. These results 
confirmed that the acidogenesis, with organic acids generation, also occurred in R2. Such evidence was confirmed with the consumption of glycerol in R2 that reached $99.9 \%$. Glycerol concentration in the influent and effluent in R2 was $291 \mathrm{mg} \mathrm{L}^{-1}( \pm 431)$ and $9 \mathrm{mg} \mathrm{L}^{-1}( \pm 17)$, respectively. In addition, only $30.7 \%$ of COD removal was verified in R2, confirming that the fermentation occurred, resulting in an effluent with COD of $8933 \mathrm{mg} \mathrm{L}^{-1}$. Veroneze et al. [43] also observed COD low removal while evaluating the biodigestion of swine manure with the addition of crude glycerin doses for biogas production in alternative biodigesters without stirring.

\subsection{Third Stage: Methanogenesis (R3)}

After $86^{\circ}$ day of the start-up, it was observed $78.7 \%$ of $\mathrm{CH}_{4}$ in the biogas composition. During the Start-up phase and Phase 1, an average of $76.3 \%$ and $85.7 \%$ of $\mathrm{CH}_{4}$ in R3, respectively. Rivero et al. [2] aiming to enhance hydrogen and methane production, used a two-stage semi-continuous CSTR with similar OLR values $\left(7.8-15.3 \mathrm{Kg} \mathrm{COD}\left(\mathrm{m}^{3} \mathrm{~d}\right)^{-1}\right)$. However, the authors observed lower proportions of $\mathrm{CH}_{4}$ in the biogas composition (50-62\% of $\mathrm{CH}_{4}$ ). Sawasdee et al. [44] aimed to enhance the $\mathrm{CH}_{4}$ production by using different glycerol/glucose ratios. The optimum condition for glycerol and COD removal was a 5:5 ratio, yielding $213.3 \mathrm{~mL} \mathrm{~g}^{-1} \mathrm{COD}\left(21.7 \% \mathrm{CH}_{4}\right)$. Dinh [45] evaluated the substrate's gradual feeding and sludge type (acclimated and non-acclimated) effect on methane production from glycerol. Reactors inoculated using a non-acclimated brewery granular sludge gradually fed with glycerol exhibited a $44.7 \%$ of $\mathrm{CH}_{4}$. In the same study, rectors fed with $100 \%$ glycerol showed just $16.1 \%$ of $\mathrm{CH}_{4}$, indicating the drastic effect of feeding shock. The values obtained in the present studied reinforce the efficiency of the system configuration used to obtain higher quantities of methane in the biogas.

During the Start-up and Phase 1, the highest volumetric methane production was $187.4 \mathrm{~L} \mathrm{CH}_{4}\left(\mathrm{~m}^{3} . \mathrm{d}\right)^{-1}$ and $283.9 \mathrm{~L} \mathrm{CH}_{4}\left(\mathrm{~m}^{3} . \mathrm{d}\right)^{-1}$ (Fig. 4). The increase in the biogas production is most likely due to OLR decrease and microbial selection throughout the experiment. The application of reactors in series allows the degradation of organic matter gradually by using the effluent of the first reactor as an effluent of a second or third one; this allows the selection of different microbial groups in separate reactors and the maximization of its activity. In the present study, with the establishment of methanogenesis in reactor R2, a more easily degradable influent was produced for reactor R3, without the need for buffering supplementation, since the part of the alkalinity was generated during the biodegradation steps, altogether with nitrogen compounds present in the domestic sewage [46].

The VFA concentration in effluent from reactor R3 during the Strat-up and Phase 1 was $2748 \mathrm{mg} \mathrm{L}^{-1}$ ( \pm 1454 ) and $636 \mathrm{mg} \mathrm{L}^{-1}( \pm 379)$, respectively (Fig. 3). The consumption of organic acids in R3 during Phase 1 was the most significant efficacy obtained consequent the $\mathrm{pH}$ increase $(8.4 \pm 0.17)$. The COD removal during start-up and phase 1 was $35.9 \%$ e $93.6 \%$, respectively, which agree with the establishment of methanogenesis in R3 (Fig. 5). In the present study, the reduction of organic matter was supposed to be seen in reactors R2 and R3 (methanogenic reactors), but it was observed higher in reactor R3 during 
phase 1; since the carbon source, glycerol, was not wholly consumed in R1, its consumption took place also in R2, and there was organic acid production and low COD removal.

The glycerol concentration present in R3's effluent during the start-up and phase 1 was 3 and $2 \mathrm{mg}$ glycerol $\mathrm{L}^{-1}$, respectively. Glycerol removals in the referred experiments were: 87.4 and $67.6 \%$. Thus, the overall glycerol removal in the system was $99.9 \%$, confirming the potential of using this system for glycerol alternate disposal/treatment along with biofuels generation.

Different reactor configurations and operational parameters have been studied to achieve better bioconversions of glycerol into $\mathrm{H}_{2}$ and $\mathrm{CH}_{4}$. Most of the initial studies were performed using batch reactors; however, recently, studies are using continuous stirred tank reactor (CSTR) and Up-Flow Anaerobic Sludge Blanket reactors (UASB). The results obtained in the present study show the potential of using a HARFB system for fermentation and methanogenesis, providing superior conversion rates of $\mathrm{H}_{2}$ and $\mathrm{CH}_{4}$, even when compared to studies that used purified glycerin (Table 3). 
Table 3

Comparative table showing the results of bioconversion of crude glycerol into biogas using different anaerobic reactors at mesophilic conditions.

\begin{tabular}{|c|c|c|c|c|c|c|}
\hline \multirow[t]{2}{*}{ Feedstock/substrate } & \multirow[t]{2}{*}{ Reactor } & OLR & $\mathrm{pH}$ & HRT & Biogas yeld & \multirow[t]{2}{*}{ Ref. } \\
\hline & & $\begin{array}{l}\mathrm{Kg} \mathrm{COD} \\
\left(\mathrm{m}^{3} \mathrm{~d}\right)^{-1}\end{array}$ & & days & $\begin{array}{l}\mathrm{mol} \mathrm{H}_{2} \\
\text { (mol Glycerol) } \\
-1\end{array}$ & \\
\hline Crude Glycerol & Batch & 14.4 & 5.7 & 24 & 0.005 & [36] \\
\hline Crude Glycerol & Batch & 54.5 & 5.2 & 84 & 0.076 & [36] \\
\hline Glycerin purified & UASB & 25.0 & 5.5 & 1 & 0.360 & [69] \\
\hline \multirow[t]{2}{*}{$\begin{array}{l}\text { 1\% Crude Glycerol + sewage } \\
(\mathrm{v} / \mathrm{v})\end{array}$} & HARFB & 13.1 & 4.89 & 1 & 0.423 & $\begin{array}{l}\text { Present } \\
\text { Study } \\
\text { (Phase1 } \\
\text { - R1) }\end{array}$ \\
\hline & & & & & $\begin{array}{l}\mathrm{m}^{3} \mathrm{CH}_{4} \\
(\mathrm{~kg} \\
\left.\mathrm{COD}_{\text {removed }}\right)^{-1}\end{array}$ & \\
\hline $\begin{array}{l}3.5 \% \text { Crude glycerol + Biodiesel } \\
\text { wastewater }(\mathrm{w} / \mathrm{v})\end{array}$ & SBR & 11.3 & 7.0 & 1 & 0.128 & [70] \\
\hline $\begin{array}{l}\text { Crude Glycerol + Acetic Acid } \\
(6: 4)\end{array}$ & Batch & 2.5 & 7.0 & 7 & 0.026 & [71] \\
\hline $\begin{array}{l}\text { 1\% Crude Glycerol + sewage } \\
(\mathrm{v} / \mathrm{v})\end{array}$ & HARFB & 6.2 & 6.4 & 2.1 & 0.117 & $\begin{array}{l}\text { Present } \\
\text { Study } \\
\text { (Start- } \\
\text { up - R2) }\end{array}$ \\
\hline $\begin{array}{l}\text { 1\% Crude Glycerol + sewage } \\
(\mathrm{v} / \mathrm{v})\end{array}$ & HARFB & 1.6 & 8.4 & 8.0 & 0.094 & $\begin{array}{l}\text { Present } \\
\text { Study } \\
\text { (Phase } \\
1-\text { R3) }\end{array}$ \\
\hline
\end{tabular}

\subsection{Microbial Diversity Analysis}

3.4.1 Microbial Relative Abundance

The inoculum source showed a relative abundance for Archaea and Bateria Domain as $40 \%$ and $60 \%$, respectively (Fig. 6). In the sample from R1 (Fermentative Reactor), the relative abundance was just 4\% 
for the Archaea Domain, while it was $96 \%$ for Bateria. Thus, the effectiveness of inoculum pre-treatment and operational conditions on microorganisms selection were confirmed. As discussed previously, those can be claimed for having selected fermentative bacteria responsible for hydrogen and organic acids production.

A different tendency was observed in the relative abundance for reactors R2 and R3 compared to the inoculum (Fig. 6). The relative abundance for Archaea and Bateria Domain were $27 \%$ and $73 \%$ for R2. Since R2 was fed with the reactor's effluent without any dilution, a high volatile organic acids concentration can be caused by the inhibition of the Archaea Domain. On the contrary, for the R3, an increase in the relative abundance for Archaea Domain was observed (55\%), and this result corroborates with methane production observed in this reactor ( $85.7 \%$ of $\mathrm{CH}_{4}$ in the composition of the biogas).

From the analysis of the relative microbial abundance in the reactors R1, R2 and R3 operated sequentially, it is possible to attest to its efficiency in creating different environments for selecting specific microbial populations to optimize the whole process of residues digestion and biofuels production.

A considerable change in the phyla composition was observed in all reactors compared to the inoculum in natura (Fig. 7). The most abundant phyla observed in the inoculum were Firmicutes (28\%), Cloacimonetes (19\%), Bacteroidetes (16\%), and Proteobacteria (14\%). The Phylum Firmicutes is known to group bacteria capable of tolerating adverse conditions by endospores forming and resisting the sludge's pre-treatment; this justifies its dominance in R1 (74\%) in comparison to the reactors R2 and R3 [47]. The second most abundant phylum in the inoculum was the Cloacimonetes, which was recently classified, and it clusters syntrophic bacteria involved in the degradation of propionate [48]. Taken into account the inoculum in natura came from a methanogenic UASB reactor, in which the production of organic acids is known, the presence of anaerobic propionate-degrading bacteria was expected. The presence of phyla Bacteroidetes and Proteobacteria were verified in samples from the inoculum, R1, R2, and R3, which groups facultative fermentative and anaerobic bacteria that have certainly contributed to the hydrogen/organic acids production verified during our experiments [49]. In reactors R2 and R3, there was no $\mathrm{H}_{2}$ detection, but instead, methane production, the most abundant phylum was also the Firmicutes ( $55 \%$ and $40 \%$, respectively). It is most likely that this abundancy is due to the diversity of strict and facultative anaerobic bacteria belonging to this phylum that can perform a wide diversity of metabolic pathways such as alcohols and volatile fatty acids [5].

Lactobacillales, belonging to the Bacteria Domain, was the most abundant order in the inoculum (13.1\%) (Fig. 7). The presence of microorganisms in this order increased in R2 (21\%), while a meager percentage was observed in R1 and R3 (3.4 and 2.3\%). Regarding the genus Lactobacillus, there was a relative abundance of $91 \%$ in reactor R2. The presence of Lactobacillus is often described in fermentative bioreactors in which acidic pHs are observed $[17,50]$. However, the presence of those microorganisms is known to be prejudicial for biohydrogen production due to the inhibition of Clostridia cells by the biocines secreted [42]. 
A different tendency was observed for the orders Bacteroidales and Clostridiales that showed relatively abundancy increased from 2.5 and $1.5 \%$ in the inoculum to $11.8 \%$ and $10.6 \%$ in R3, respectively. Thus, it is possible that the operational conditions applied to the reactors, including the carbon source used, favored their establishment in the reactors.

Members of this order, such as Clostridium sp. have already been described with the ability to consume different carbon sources through hydrolysis, culminating with organic acids and hydrogen generation, among other metabolic pathways [51]. The high relative abundance of the order Clostridiales in reactor R3 (10.6\%) suggests there were still compounds to be consumed or an environmental condition that could favor/select these endospore-forming cells.

In reactor R1, the order with the highest relative abundance was Selenomonadales (61.3\%) and genus Megasphaera (29\%), which groups lactic acid consuming microorganisms that can produce $\mathrm{H}_{2}$ [52]. However, there was a reduced production of $\mathrm{H}_{2}$ in R1 when compared to the theoretical production.

The maintenance of different hydrogen-producing microorganisms can be related to the synergism between species that have already been reported in several bioreactors. Strains of Enterobacteriaceae were observed contributing to the production of $\mathrm{H}_{2}$ and Clostridium in a CSTR fed with glucose [53]. The synergism between the orders Enterobacteriales and Bacteroidales was reported in packaged bed reactors in which Clostridium spp. developed an association with Klebsiella and Prevotella, which can agglutinate with other microorganisms $[49,54]$. These groups of microorganisms in the R1 reactor may explain the low relative abundance of individuals of the order Clostridiales in a fermentative reactor with $\mathrm{H}_{2}$ production. The microbial consortium can benefit from this synergism between species and stand out in the production of $\mathrm{H}_{2}$ when compared to communities dominated by Clostridium.

Luo et al. [55] used a continuous flow bioreactor inoculated with thermally treated agricultural soil and fed with glucose. They observed a diversified selection of microbial communities (Selenomonas, Enterobacter, and Clostridium spp). This fact resulted in the highest hydrogen production yield compared to the community dominated by Clostridium observed in higher OLRs.

For the Archaea domain present in the acidogenic reactor (R1), the relative abundance of $4 \%$ of Methanobacteriales was higher when compared to the inoculum (0.8\%). In addition, these known $\mathrm{H}_{2}-$ consuming microorganisms are also capable of assimilating methanol [56], which may be present in crude glycerol, favoring its permanence in R1 and justifying the reduced $\mathrm{H}_{2}$ production.

The order Methanosarcinales had the highest relative abundance in the methanogenic reactors, presenting $17.6 \%$ and $35.7 \%$ in the $\mathrm{R} 2$ and $\mathrm{R} 3$ reactors, respectively. Thus, these microorganisms were likely responsible for the expressive $\mathrm{CH}_{4}$ generation that occurred during the experiments.

The genetic sequencing of the inoculum in natura and the composing samples retrieved from the reactor at the end of phase 1 have clearly shown the microbiota changes due to substrate modification operational conditions imposed on the 3-stage bioreactors. 


\subsubsection{Microbial Community Structure - DGGE 3.4.2.1 Bacteria Domain}

Figure 8 shows a dendrogram and the Jaccard similarity index calculated for the Bacteria Domain. The samples were clustered in 2 main groups: (1) all reactor R1 and (2) samples from reactors R2, R3, and the inoculum.

A high similarity (93\%) was verified between the central and end portion of reactor R1 (R1P2b and R1P3b). Probably, the highest OLR and potentially toxic compounds could have impacted the bacterial community of the first section of the reactor R1 (R1P1b) than the intermediate and final sections. However, it is worth emphasizing that the similarity of R1P2b and R1P3b with the R1P1b is $60 \%$.

Another essential comparison is with the inoculum (INOCb) with the bacterial community from reactor R1, which was $44 \%$. In other words, the pre-treatment of the inoculum inactivated populations, causing many of them to disappear along the first reactor. The higher the OLR, the lower the community similarity; organic loading rate shocks act by selecting more resistant individuals [36].

A similar pattern was observed by Silva et al. (2019), who studied a fluidized bed reactor to treat dairy wastewater under different OLRs. $90 \%$ similarity was observed at $28.7,53.2 \mathrm{Kg} \operatorname{COD}\left(\mathrm{m}^{3} . \mathrm{d}\right)^{-1}$ conditions, and $70 \%$ at $95.76 \mathrm{Kg} \mathrm{COD}\left(\mathrm{m}^{3} . \mathrm{d}\right)^{-1}$. The piston flow of the AFBR acted selecting specific bacteria on different sections inside the reactor, as the initial portion receives major OLRs, it allows and pushes for a longitudinally oriented selection of species.

In Reactor R2, 74\% of similarity was observed between the initial and central portions of the reactor (R2P1b e R2P2b). This cluster was $52 \%$ similar to the end portion of this reactor (R2P3b) (Fig. 8). The changes in the bacterial community were expected due to the piston flow and the design of the system set-up operated in series. As per reactors and system configuration, the effluent of one reactor will be used as the influent for the next one contributing to the microbial selection.

To summarize, similarly to what was observed in R2, a methanogenic reactor, the intermediate and end sections of R3 were more similar between themselves. These sections were possibly colonized by microbial populations capable of generating methane from similar substrates. Different results were reported when batch reactors were used for $\mathrm{H}_{2}$ production; higher similarities between their populations were observed $87 \%$ by Zhao et al. (2010) and $98 \%$ by Maintinguer et al. [35]. Pre-treatments and operational conditions such as higher $\mathrm{pH}$ and temperature range play an essential role. This difference may have occurred due to factors such as the reactor configuration and the more extended experimental period (260 days) in our HARFB system, which contributed to species selection, increasing the diversity in the reactors.

According to the Shannon-Wiener index ( $\mathrm{H}$ index) for the Bacteria Domain, higher diversity was observed in the $\mathrm{R} 3$ reactor: $3.17,3.27$, and 3.19 for sampling points $\mathrm{P} 1, \mathrm{P} 2$, and $\mathrm{P} 3$, respectively (Table 4). These 
results are comparable with the inoculum diversity index (3.28). Furthermore, it is noteworthy that the inoculum came from a methanogenic reactor and the operational conditions applied for the R2 and R3 reactors were set to favor methane generation, corroborating the high diversity in the R3 reactor, as observed in the inoculum.

Table 4

Shannon-Wiener index ( $\mathrm{H}$ index) to Bacteria domain

\begin{tabular}{|llllllllll|}
\hline Inoculum & R1 & \multicolumn{3}{c}{ R2 } & \multicolumn{5}{c|}{ R3 } \\
\cline { 2 - 11 } & P1 & P2 & P3 & P1 & P2 & P3 & P1 & P2 & P3 \\
\hline 3.28 & 2.60 & 2.91 & 2.80 & 3.25 & 3.15 & 3.09 & 3.17 & 3.27 & 3.19 \\
\hline
\end{tabular}

The lowest diversity index (2.60) was found for the first sampling point in R1; this can be explained due to the pre-treatment applied to the inoculum for fermentative microorganisms' selection and acidic $\mathrm{pH}$ imposed (5.5). The same was observed by Abreu et al. (2011) in their study for hydrogen production from a mixture of glucose $(13 \mathrm{mM})$ and L-arabinose $(16 \mathrm{mM})$, at $37^{\circ} \mathrm{C}$, and $\mathrm{pH} 5.5$. Additionally, the highest OLR these microorganisms were exposed to also contributed to its lowest diversity. Contrary, reactors R2 and R3, being feed with reactor's R1 and reactor's R2 effluent, respectively, received lower glycerol load in comparison to R1, but certainly higher in volatile organic acids [60-62].

Although showing the lowest diversity index if compared to all reactors, R1's diversity was still high. Pachiega et al. [17] studied batch reactors fed with sucrose and inoculated with granular sludge from a UASB reactor treating brewery wastewater; the authors observed an $\mathrm{H}$ index of 0.78 for the sample of tropical sludge pretreated ( $\mathrm{pH} 5.5$ + heat treatment). Reactor's type, system configuration, inoculum source (initial diversity), pre-treatment method, carbon source, and operational conditions (OLR, temperature, $\mathrm{pH}$ ) play a role in microorganisms' selection, and it is impossible to determine which of all the listed factors weighed more. The main drawback of the high microbial diversity is having hydrogenconsuming microorganisms co-existing with hydrogen-producers [63, 64]. Silva et al. [57] observed a correlation between OLR and microbial diversity. For these authors, the higher the OLR, the higher the diversity (2.205 to 2.811); however, the opposite trend was seen for $\mathrm{H}_{2}$ production. In the present study, the unstable and lowest hydrogen production obtained during the start-up phase could be due to the impact of OLR on microbial diversity. The same trend was observed in a study aiming to evaluate the microbial profile of water reservoir sediments against organic matter concentration and nutrients such as nitrogen and phosphorus [65].

In reactors $\mathrm{R} 2(>3.09)$ and $\mathrm{R} 3(>3.17)$, the microbial diversity was higher in comparison to the first reactor (<2.91). As the system comprises 3-series reactors, the volatile fatty acids and alcohols rich-effluent with reduced glycerol load seem to have played an important role in microorganisms' diversity in R2 and R3. 
Furthermore, $\mathrm{NaHCO}_{3}$ supplementation in R2's influent to mimic an optimal pH environment for establishing methanogens could have also affected positively for its diversity.

\subsubsection{Domain Archaea}

DGGE profiles for the Domain Archaea revealed significant structural differences between the inoculum and samples from the reactors after 260 days; the similarity index was less than $15 \%$. This result can be attributed to the pre-treatment applied to the inoculum and the operational conditions that the microorganisms were exposed to during the experimental period. It was also observed that a reduced similarity between the samples of each reactor. In reactor R1, the lowest similarity was between sampling points R1P2a and R1P3a (50\%) and in reactor R2 between R2P1a and R2P3a (40\%). Based on this analysis, it was possible to observe the impact of inoculum pre-treatment, substrate composition, and operational conditions on the microbial community. The spatial selection of microorganisms throughout the reactor could be attributed to the reactor's configuration - plug flow - as per its definition, the carbon source/substrate the microorganisms were exposed to within the same bioreactors varies (Fig. 9).

Figure 9 clearly shows that all the samples taken from the reactors were clustered together; however, in a separate branch from the inoculum ( $10 \%)$. These results confirm the selection of different microbial communities either due to the acidic pre-treatment to the inoculum was subjected to the environmental conditions the microorganisms were exposed to during the experimental period ( 260 days).

The sample from the first point of the system (R1P1a) was not grouped with other samples (less than $30 \%$ similar) nor with the inoculum, suggesting the pre-treatment impact in the microbial populations. The central and end regions of R1 (R1P2a and R1P3a) showed 50\% similarity, indicating a more similar environmental condition in these two sections of the reactor. Samples from the reactor R2 were either grouped with samples from R1 and R3. The central portion of the reactor R2P2a was grouped with the central and end region of reactor R1. In a different cluster, it was grouped R2P1a and R2P3a ( $>40 \%$ similarity).

In reactor $\mathrm{R} 3$, the sample R3P1a, collected from the reactor's initial part, was grouped with samples from the reactor R2: R2P1a and R2P3a (35\% similarity) (Fig. 9). As the R3 was fed with the effluent from R2, probably the substrate composition favored the selection of a similar microbial community. However, the last sampling point of the system (R3P3a) was not grouped with any other sample analyzed, showing less than $20 \%$ similarity with them. As being the last part of a system composed of 3-reactors operated in series and fed with the effluent of the precedent reactor, the lack of carbon source $(99.9 \%$ of overall glycerol removal was achieved) could be the reason for such difference. It was impossible to analyze the sample R3P2a (sampling point R3 central position) due to a DNA amplification limitation.

Archaea microorganisms have high sensitivity to environmental fluctuations. It includes substrate-fed shocks occurring during the reactor's start-up phase and justifies the low similarities of $15-50 \%$ among all present study samples. Silva et al. [66] obtained similar results by analyzing the microbiota from the 
inoculum and the first chamber of a pilot-scale compartmented reactor used for the treatment of sanitary sewage and in reduced OLR $\left(0.10 \mathrm{~kg} \operatorname{COD}\left(\mathrm{m}^{3} \mathrm{~d}\right)^{-1}\right)$; it was observed a $51 \%$ of similarity.

The highest diversity Shannon-Wiener index for the Archaea Domain was observed for sampling points R2P2a for R2 (2.25) and R3P3a for R3 (2.27). Both values were higher than that observed for the inoculum (1.99). The lowest diversity index, as expected, occurred in the first sampling point of the fermentative reactor R1 (1.58) since the sludge was subjected to the acidic pre-treatment, which aimed to select endospore-forming bacteria, including the methanogens (Table 5).

Table 5

Shannon-Wiener index ( $\mathrm{H}$ index) to Archaea domain

\begin{tabular}{|llllllllll|}
\hline Inoculum & R1 & \multicolumn{3}{c}{ R2 } & \multicolumn{5}{c|}{ R3 } \\
\cline { 2 - 10 } & P1 & P2 & P3 & P1 & P2 & P3 & P1 & P2 & P3 \\
\hline 1.99 & 1.58 & 1.71 & 1.99 & 2.09 & 2.25 & 2.01 & 2.22 & - & 2.27 \\
\hline
\end{tabular}

\subsection{Scanning electron microscopy}

Scanning electron microscopy analysis allowed the morphological identification of methanogenic microorganisms in granular sludge samples taken from reactors 2 and 3 and identification of cells morphologies inside hydrogen-producing bioreactor (R1) (Fig. 10). Exopolymers (EPS), which are biopolymers produced by microbial cells during specific metabolic processes, have been observed throughout the granular structure, and EPS has clustered a large number of bacterial cells. A series of tunnels/channels were also observed due to the granule extension, which was probably used in syntrophic relationships (food intake, gas output) intra and inter-species and populations of anaerobic microorganisms [67]. The granular sludge from the UASB reactor kept its morphology/activity after being transferred to the HARFB; this is extremely important; besides the biofilm formed and attached to the material support, this interstitial granular sludge helps to avoid the microbial washout.

Cell morphologies similar to microorganisms belonging to the genera Methanosaeta (Fig. 10B) and Methanosarcina (Fig. 10C and D) were observed in samples from R2 and R3. It is most likely that the production of acetic acid was notable in the bioreactors because the genus Methanosarcina has a greater affinity for this carbon source and can grow in nutritional media with reduced $\mathrm{pH}$ [68].

\section{Practical Application And Future Perspectives}

Due to political support for biodiesel production policies, its production has increased gradually, as well as one of its end-product, crude glycerol. In this scenario, the problem to solve is appropriate disposal for this residue, which has boosted research worldwide on this topic. Furthermore, there is an interest in applying this carbon source for biofuel generation using microorganisms for catalyzing the process. In 
this context, the analysis of the composition of microorganism's populations inside bioreactors has been crucial for understanding how external conditions induce the amount and role of different microbial groups during the process. In the present study, it was possible to observe the microbial selection inside one reactor, compare them to other reactors in the system and their variations when operational conditions have changed. Based on our findings and the low cost of implementation/operation, a 3stage-system of HARFB could be installed in biodiesel production plants for on-site crude glycerol treatment (blended with domestic sewage) along with energy generation that could be used in the heating processes, lowering the overall production cost.

\section{Conclusions}

The inoculum pre-treatment was efficient in inhibiting methanogenic microorganisms in R1, avoiding hydrogen consumption in this environment. The reduction of OLR, by increasing the TDH, positively influenced biogas production and COD removal, being a good strategy for reactor start-up. DS successfully diluted toxic compounds in crude glycerol; thus, its concentration did not inhibit hydrogen and methane-producing microorganisms $\left(0.42 \mathrm{~mol} \mathrm{H}_{2} \mathrm{~mol}^{-1}\right.$ glycerol,311.9 e $283.9 \mathrm{~L} \mathrm{CH}_{4}\left(\mathrm{~m}^{3} \mathrm{~d}\right)^{-1}$ for reactors $\mathrm{R} 1, \mathrm{R} 2$, and $\mathrm{R} 2$, respectively). Changes in the microbial diversity in all three bioreactors confirmed that the operational conditions played an important role in selecting microorganisms along with the pistoned flow of the HARFB. Higher microbial diversities were observed inside methanogenic reactors (R2 and R3) in comparison to the fermentative reactor (R1), which was inoculated with an acidic pre-treated inoculum. The overall glycerol consumption and COD removal show the potential of using a 3-series HARFB to recuperate bioenergy from an important industrial waste.

\section{Declarations}

\section{Funding}

This work was supported by the Conselho Nacional de Desenvolvimento Científico e Tecnológico (CNPQ) under Grant 407298/2018-5 and 457144/2014-9; and Fundação de Amparo à Pesquisa do Estado de São Paulo (FAPESP) under Grant 2017/11767-1 and 2017/25329-6. The authors are also grateful to the "Coordenação de Aperfeiçoamento de Pessoal de Nível Superior - Brasil" (CAPES) - Finance Code 001.

\section{Competing interests}

The authors have no competing interests to declare that are relevant to the content of this article.

\section{Availability of data and materials}

DNA sequences data were deposited in NCBI genetic sequence database, Project name PRJNA531496, Bioproject PRJNA531496, Inoculum: Biosample SAMN15438363 (SRA: SRR12192782); R1: Biosample SAMN15438259 (SRA: SRR12192195); R2: Biosample SAMN15438265 (SRA: SRR12192464); R3: Biosample SAMN15438362 (SRA: SRR12192644). 


\section{Authors 'contributions}

All authors contributed to the study conception and design. Material preparation, data collection and analysis were performed by Luan Vieira Adames, Ana Paula Jacobus and Isabel Sakamoto. Funding acquisition, advising and experimental outline was made my Sandra Imaculada Maintinguer and Lorena Oliveira Pires. The first draft of the manuscript was written by Luan Vieira Adames, English revised by Carolina Zampol Lázaro and all authors commented on previous versions of the manuscript. All authors read and approved the final manuscript and consented to submission for publication.

\section{References}

1. Maintinguer SI, Hatanaka RR, Oliveira JE de (2015) Glycerol as a Raw Material for Hydrogen Production. In: Biofuels - Status and Perspective. InTech, p 580

2. Rivero M, Solera R, Perez M (2014) Anaerobic mesophilic co-digestion of sewage sludge with glycerol: Enhanced biohydrogen production. International Journal of Hydrogen Energy 39:24812488. https://doi.org/10.1016/j.ijhydene.2013.12.006

3. Rodrigues CV, Oliveira Santana K, Nespeca MG, et al (2020) Energy valorization of crude glycerol and sanitary sewage in hydrogen generation by biological processes. International Journal of Hydrogen Energy 45:11943-11953. https://doi.org/10.1016/j.ijhydene.2020.02.168

4. Pachauri N, He B (2006) Value-added Utilization of Crude Glycerol from Biodiesel Production: A Survey of Current Research Activities. American Society of Agriculture and Biological Engineers 0300:1-16. https://doi.org/10.1080/15422119.2013.851696

5. Rodrigues CV, Nespeca MG, Sakamoto IK, et al (2019) Bioconversion of crude glycerol from waste cooking oils into hydrogen by sub-tropical mixed and pure cultures. International Journal of Hydrogen Energy 4:144-154. https://doi.org/10.1016/j.jhydene.2018.02.174

6. Sawasdee V, Haosagul S, Pisutpaisal N (2019) ScienceDirect Co-digestion of waste glycerol and glucose to enhance biogas production. International Journal of Hydrogen Energy. https://doi.org/10.1016/j.ijhydene.2019.03.144

7. Meier TRW, Cremonez PA, Maniglia TC, et al (2020) Production of biohydrogen by an anaerobic digestion process using the residual glycerol from biodiesel production as additive to cassava wastewater. Journal of Cleaner Production 258:. https://doi.org/10.1016/j.jclepro.2020.120833

8. Kaur J, Sarma AK, Jha MK, Gera P (2020) Valorisation of crude glycerol to value-added products: Perspectives of process technology, economics and environmental issues. Biotechnology Reports 27:e00487. https://doi.org/10.1016/j.btre.2020.e00487

9. Chilakamarry CR, Sakinah AMM, Zularisam AW, et al (2021) Bioconversion of Glycerol into BiofuelsOpportunities and Challenges. BioEnergy Research. https://doi.org/10.1007/s12155-021-10353-6

10. Aydin S, Shahi A, Ozbayram EG, et al (2015) Use of PCR-DGGE based molecular methods to assessment of microbial diversity during anaerobic treatment of antibiotic combinations. Bioresource Technology 192:735-740. https://doi.org/10.1016/j.biortech.2015.05.086 
11. Robles Á, Aguado D, Barat R, et al (2020) New frontiers from removal to recycling of nitrogen and phosphorus from wastewater in the Circular Economy. Bioresource Technology 300:122673. https://doi.org/10.1016/j.biortech.2019.122673

12. Li D, Li W, Zhang K, et al (2020) Nutrient removal by full-scale Bi-Bio-Selector for nitrogen and phosphorus removal process treating urban domestic sewage at low $\mathrm{C} / \mathrm{N}$ ratio and low temperature conditions. Process Safety and Environmental Protection 140:199-210. https://doi.org/10.1016/j.psep.2020.05.011

13. Li Y, Chen Y, Wu J (2019) Enhancement of methane production in anaerobic digestion process: $A$ review. Applied Energy 240:120-137. https://doi.org/10.1016/j.apenergy.2019.01.243

14. Aydin S, Ince B, Ince $O$ (2015) Application of real-time PCR to determination of combined effect of antibiotics on Bacteria, Methanogenic Archaea, Archaea in anaerobic sequencing batch reactors. Water Research 76:88-98. https://doi.org/10.1016/j.watres.2015.02.043

15. Wang X, Cui $H$, Shi J, et al (2015) Relationship between bacterial diversity and environmental parameters during composting of different raw materials. Bioresource Technology 198:395-402. https://doi.org/10.1016/j.biortech.2015.09.041

16. Malin C, Illmer P (2008) Ability of DNA content and DGGE analysis to reflect the performance condition of an anaerobic biowaste fermenter. Microbiological Research 163:503-511. https://doi.org/10.1016/j.micres.2007.07.004

17. Pachiega R, Sakamoto IK, Varesche MB, et al (2018) Obtaining and Characterization of Mesophilic Bacterial Consortia from Tropical Sludges Applied on Biohydrogen Production. Waste and Biomass Valorization. https://doi.org/10.1007/s12649-017-0185-6

18. Rossi DM, Berne Da Costa J, Aquino De Souza E, et al (2011) Comparison of different pretreatment methods for hydrogen production using environmental microbial consortia on residual glycerol from biodiesel. International Journal of Hydrogen Energy 36:4814-4819. https://doi.org/10.1016/j.ijhydene.2011.01.005

19. ZAIAT M, CABRAL AKA, FORESTI E (1994) Reator Anaeróbio Horizontal de Leito Fixo Para Tratamento de Águas Residuárias: Concepção e Avaliação Preliminar de Desempenho. Revista Brasileira de Engenharia 11:33-42

20. APHA, AWWA, WEF (2005) Standard Methods for the Examination of Water and Wastewater, 21 st ed. American Public Health Association, Washington DC, USA.

21. Jenkins SR, Morgan JM, Sawyer CL (1983) Measuring anaerobic sludge digestion and growth by a simple alkalimetric titration. Journal of Water Pollution 55:448-453

22. DiLallo R, Albertson OE (1961) Volatile acids by direct titration. Journal of Water Pollution 33:356

23. Zuo X, Yuan H, Wachemo AC, et al (2019) The relationships among SCOD, VFAs, microbial community, and biogas production during anaerobic digestion of rice straw pretreated with ammonia. Chinese Journal of Chemical Engineering 1-7. https://doi.org/10.1016/j.cjche.2019.07.015 
24. Neto JG, Santos VG, Andreguetto LG, et al (2014) Quantificação de biogás em reatores anaeróbios através do método de deslocamento de volume de água. Revista de Estudos Ambientais 16:45-53

25. MAINTINGUER S, FERNANDES B, DUARTE I, et al (2008) Fermentative hydrogen production by microbial consortium. International Journal of Hydrogen Energy 33:4309-4317. https://doi.org/10.1016/j.ijhydene.2008.06.053

26. Nation JL (1983) A New Method Using Hexamethyldisilazane for Preparation of Soft Insect Tissues for Scanning Electron Microscopy. Stain Technology 58:347-351. https://doi.org/10.3109/10520298309066811

27. Griffiths RI, Whiteley AS, O'Donnell AG, Bailey MJ (2000) Rapid method for coextraction of DNA and RNA from natural environments for analysis of ribosomal DNA- and rRNA-based microbial community composition. Applied and Environmental Microbiology 66:5488-5491. https://doi.org/10.1128/AEM.66.12.5488-5491.2000

28. Magoč T, Salzberg SL (2011) FLASH: Fast length adjustment of short reads to improve genome assemblies. Bioinformatics 27:2957-2963. https://doi.org/10.1093/bioinformatics/btr507

29. Caporaso JG, Kuczynski J, Stombaugh J, et al (2010) QIIME allows analysis of high-throughput community sequencing data. Nature Methods 7:335-336. https://doi.org/10.1038/nmeth.f.303

30. Bokulich NA, Subramanian S, Faith JJ, et al (2013) Quality-filtering vastly improves diversity estimates from Illumina amplicon sequencing. Nature Methods 10:57-59. https://doi.org/10.1038/nmeth.2276

31. Edgar RC, Haas BJ, Clemente JC, et al (2011) UCHIME improves sensitivity and speed of chimera detection. Bioinformatics 27:2194-2200. https://doi.org/10.1093/bioinformatics/btr381

32. Haas BJ, Gevers D, Earl AM, et al (2011) Chimeric 16S rRNA sequence formation and detection in Sanger and 454-pyrosequenced PCR amplicons. Genome Research 21:494-504. https://doi.org/10.1101/gr.112730.110

33. Nubel U, Engelen B, Felske A, et al (1996) Sequence heterogeneities of genes encoding 16।thinspaceS rRNAs in Paenibacillus polymyxa detected by temperature gradient gel electrophoresis. J Bacteriol 178:5636-5643. https://doi.org/10.1128/jb.178.19.5636-5643.1996

34. Kudo Y, Nakajima T, Miyaki T, Oyaizu H (2006) Methanogen flora of paddy soils in Japan. FEMS Microbiology Ecology 22:39-48. https://doi.org/10.1111/j.1574-6941.1997.tb00354.x

35. Maintinguer SI, Sakamoto IK, Adorno MAT, Varesche MBA (2015) Bacterial diversity from environmental sample applied to bio-hydrogen production. International Journal of Hydrogen Energy 40:3180-3190. https://doi.org/10.1016/j.ijhydene.2014.12.118

36. Vasconcelos EAF, Santaella ST, Viana MB, et al (2019) Composition and ecology of bacterial and archaeal communities in anaerobic reactor fed with residual glycerol. Anaerobe 59:145-153. https://doi.org/10.1016/j.anaerobe.2019.06.014

37. Jiraprasertwong A, Seneesrisakul K, Pornmai K, Chavadej S (2020) High methanogenic activity of a three-stage UASB in relation to the granular sludge formation. Science of the Total Environment 724:138145. https://doi.org/10.1016/j.scitotenv.2020.138145 
38. Seifert K, Waligorska M, Wojtowski M, Laniecki M (2009) Hydrogen generation from glycerol in batch fermentation process. International Journal of Hydrogen Energy 34:3671-3678. https://doi.org/10.1016/j.ijhydene.2009.02.045

39. Sarma SJ, Brar SK, Sydney EB, et al (2012) Microbial hydrogen production by bioconversion of crude glycerol: A review. International Journal of Hydrogen Energy 37:6473-6490. https://doi.org/10.1016/j.ijhydene.2012.01.050

40. Selembo PA, Perez JM, Lloyd WA, Logan BE (2009) Enhanced hydrogen and 1,3-propanediol production from glycerol by fermentation using mixed cultures. Biotechnology and Bioengineering 104:1098-1106. https://doi.org/10.1002/bit.22487

41. Ngo TA, Kim MS, Sim SJ (2011) High-yield biohydrogen production from biodiesel manufacturing waste by Thermotoga neapolitana. International Journal of Hydrogen Energy 36:5836-5842. https://doi.org/10.1016/j.ijhydene.2010.11.057

42. Veras STS, Rojas P, Florencio L, et al (2019) Production of 1,3-propanediol from pure and crude glycerol using a UASB reactor with attached biomass in silicone support. Bioresource Technology 279:140-148. https://doi.org/10.1016/j.biortech.2019.01.125

43. Veroneze ML, Schwantes D, Gonçalves AC, et al (2019) Production of biogas and biofertilizer using anaerobic reactors with swine manure and glycerin doses. Journal of Cleaner Production 213:176184. https://doi.org/10.1016/j.jclepro.2018.12.181

44. Sawasdee V, Haosagul S, Pisutpaisal N (2019) Co-digestion of waste glycerol and glucose to enhance biogas production. International Journal of Hydrogen Energy 44:29575-29582. https://doi.org/10.1016/j.ijhydene.2019.03.144

45. Dinh NT (2020) A novel enhancement for the start-up of methane fermentation reactor by inoculating the acclimated sludge as a seeding material. IOP Conference Series: Materials Science and Engineering 736:. https://doi.org/10.1088/1757-899X/736/4/042041

46. Speece RE (2008) Anaerobic Biotechnology and Odor/Corrosion Control for Municipalities and Industries. Archae Press, Nashville, Tennessee

47. Filippidou S, Junier T, Wunderlin T, et al (2015) Under-detection of endospore-forming Firmicutes in metagenomic data. Computational and Structural Biotechnology Journal 13:299-306. https://doi.org/10.1016/j.csbj.2015.04.002

48. Ahlert S, Zimmermann R, Ebling J, König H (2016) Analysis of propionate-degrading consortia from agricultural biogas plants. MicrobiologyOpen 5:1027-1037. https://doi.org/10.1002/mbo3.386

49. Maintinguer SI, Fernandes BS, Duarte ICS, et al (2011) Fermentative hydrogen production with xylose by Clostridium and Klebsiella species in anaerobic batch reactors. International Journal of Hydrogen Energy 36:13508-13517. https://doi.org/10.1016/j.ijhydene.2011.07.095

50. Wu Y, Wang C, Liu X, et al (2016) A new method of two-phase anaerobic digestion for fruit and vegetable waste treatment. Bioresource technology 211:16-23. https://doi.org/10.1016/j.biortech.2016.03.050 
51. Zhao Y, Wu J, Yuan X, et al (2017) The effect of mixing intensity on the performance and microbial dynamics of a single vertical reactor integrating acidogenic and methanogenic phases in lignocellulosic biomass digestion. Bioresource Technology 238:542-551. https://doi.org/10.1016/j.biortech.2017.04.080

52. Castelló E, García y Santos C, Iglesias T, et al (2009) Feasibility of biohydrogen production from cheese whey using a UASB reactor: Links between microbial community and reactor performance. International Journal of Hydrogen Energy 34:5674-5682. https://doi.org/10.1016/j.ijhydene.2009.05.060

53. Song J, An D, Ren N, et al (2011) Effects of pH and ORP on microbial ecology and kinetics for hydrogen production in continuously dark fermentation. Bioresource Technology 102:10875-10880. https://doi.org/10.1016/j.biortech.2011.09.024

54. Li C, Zhang T, Fang HHP (2006) Fermentative hydrogen production in packed-bed and packaging-free upflow reactors. Water Science and Technology 54:95-103. https://doi.org/10.2166/wst.2006.712

55. Luo $Y$, Zhang $H$, Salerno $M$, et al (2008) Organic loading rates affect composition of soil-derived bacterial communities during continuous, fermentative biohydrogen production. International Journal of Hydrogen Energy 33:6566-6576. https://doi.org/10.1016/j.ijhydene.2008.08.047

56. Bonin AS, Boone DR (2006) The Order Methanobacteriales Characteristics of Methanobacteriales. Prokaryotes 3:231-243. https://doi.org/10.1007/0-387-30743-5_11

57. Silva AN da, Macêdo WV, Sakamoto IK, et al (2019) Biohydrogen production from dairy industry wastewater in an anaerobic fluidized-bed reactor. Biomass and Bioenergy 120:257-264. https://doi.org/10.1016/j.biombioe.2018.11.025

58. Zhao C, Karakashev D, Lu W, et al (2010) Xylose fermentation to biofuels (hydrogen and ethanol) by extreme thermophilic $\left(70^{\circ} \mathrm{C}\right)$ mixed culture. International Journal of Hydrogen Energy 35:34153422. https://doi.org/10.1016/j.jijhydene.2010.01.082

59. Abreu AA, Alves JI, Pereira MA, et al (2011) Strategies to suppress hydrogen-consuming microorganisms affect macro and micro scale structure and microbiology of granular sludge. Biotechnology and Bioengineering 108:1766-1775. https://doi.org/10.1002/bit.23145

60. Marzorati M, Wittebolle L, Boon N, et al (2008) How to get more out of molecular fingerprints: Practical tools for microbial ecology. Environmental Microbiology 10:1571-1581. https://doi.org/10.1111/j.1462-2920.2008.01572.x

61. Viana MB, Freitas A v., Leitão RC, et al (2012) Anaerobic digestion of crude glycerol: a review. Environmental Technology Reviews 1:81-92. https://doi.org/10.1080/09593330.2012.692723

62. Lebrero R, Rodríguez E, Pérez R, et al (2013) Abatement of odorant compounds in one- and twophase biotrickling filters under steady and transient conditions. Applied Microbiology and Biotechnology 97:4627-4638. https://doi.org/10.1007/s00253-012-4247-1

63. Traversi D, Bonetta S, Degan R, et al (2013) Environmental Advances Due to the Integration of Food Industries and Anaerobic Digestion for Biogas Production: Perspectives of the Italian Milk and Dairy Product Sector. Bioenergy Research 6:851-863. https://doi.org/10.1007/s12155-013-9341-4 
64. Valdez-Vazquez I, Poggi-Varaldo HM (2009) Hydrogen production by fermentative consortia. Renewable and Sustainable Energy Reviews 13:1000-1013.

https://doi.org/10.1016/j.rser.2008.03.003

65. Maintinguer SI, Sakamoto IK, Adorno MAT, Varesche MBA (2016) Diversity of anaerobic bacteria in sediments from a subtropical reservoir. Lakes and Reservoirs: Research and Management 21:351361. https://doi.org/10.1111//re.12156

66. Silva FMS, Oliveira LB, Mahler CF, Bassin JP (2017) Hydrogen production through anaerobic codigestion of food waste and crude glycerol at mesophilic conditions. International Journal of Hydrogen Energy 42:22720-22729. https://doi.org/10.1016/j.ijhydene.2017.07.159

67. Baloch MI, Akunna JC, Kierans M, Collier PJ (2008) Structural analysis of anaerobic granules in a phase separated reactor by electron microscopy. Bioresource Technology 99:922-929. https://doi.org/10.1016/j.biortech.2007.03.016

68. Kendall MM, Boone DR (2006) The Order Methanosarcinales. Prokaryotes Vol 6 244-256. https://doi.org/10.1007/0-387-30743-5_12

69. Sittijunda S, Reungsang A (2017) Fermentation of hydrogen, 1,3-propanediol and ethanol from glycerol as affected by organic loading rate using up-flow anaerobic sludge blanket (UASB) reactor. International Journal of Hydrogen Energy 42:27558-27569.

https://doi.org/10.1016/j.ijhydene.2017.05.149

70. Tangkathitipong P, Intanoo P, Butpan J (2017) Separate production of hydrogen and methane from biodiesel wastewater with added glycerin by two-stage anaerobic sequencing batch reactors ( ASBR ). Renewable Energy 113:1077-1085. https://doi.org/10.1016/j.renene.2017.06.056

71. Haosagul S, Vikromvarasiri N, Sawasdee V, Pisutpaisal N (2019) Impact of acetic acid in methane production from glycerol/acetic acid co-fermentation. International Journal of Hydrogen Energy 44:29568-29574. https://doi.org/10.1016/j.ijhydene.2019.03.204

\section{Figures}

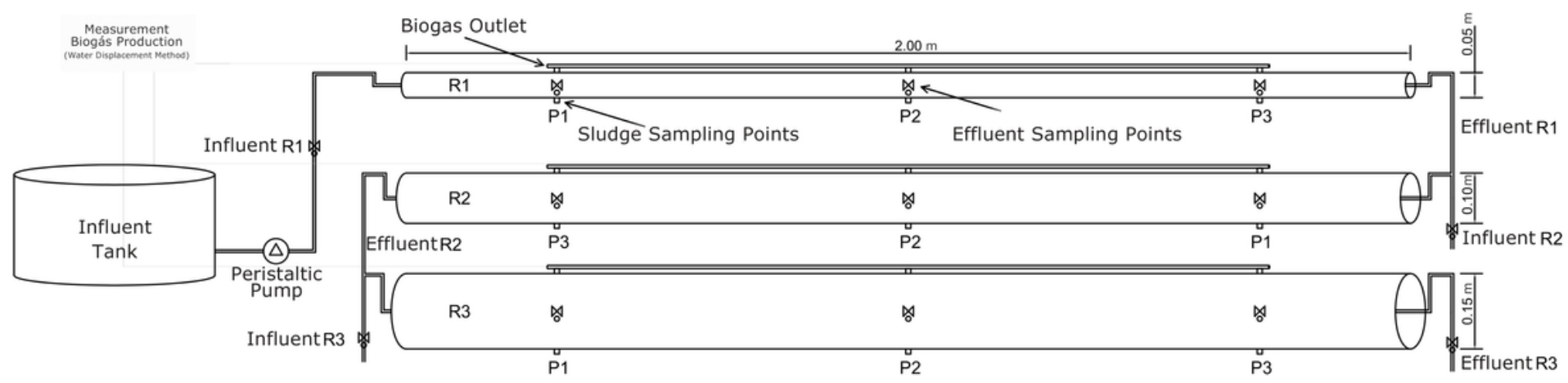

\section{Figure 1}


Schematic representation of three horizontal anaerobic reactors with fixed-bed (HARFB) in-series (R1, R2, and R3), Influent, Effluent, Biogas outlets, Sludge sampling points (P1, P2, and P3)

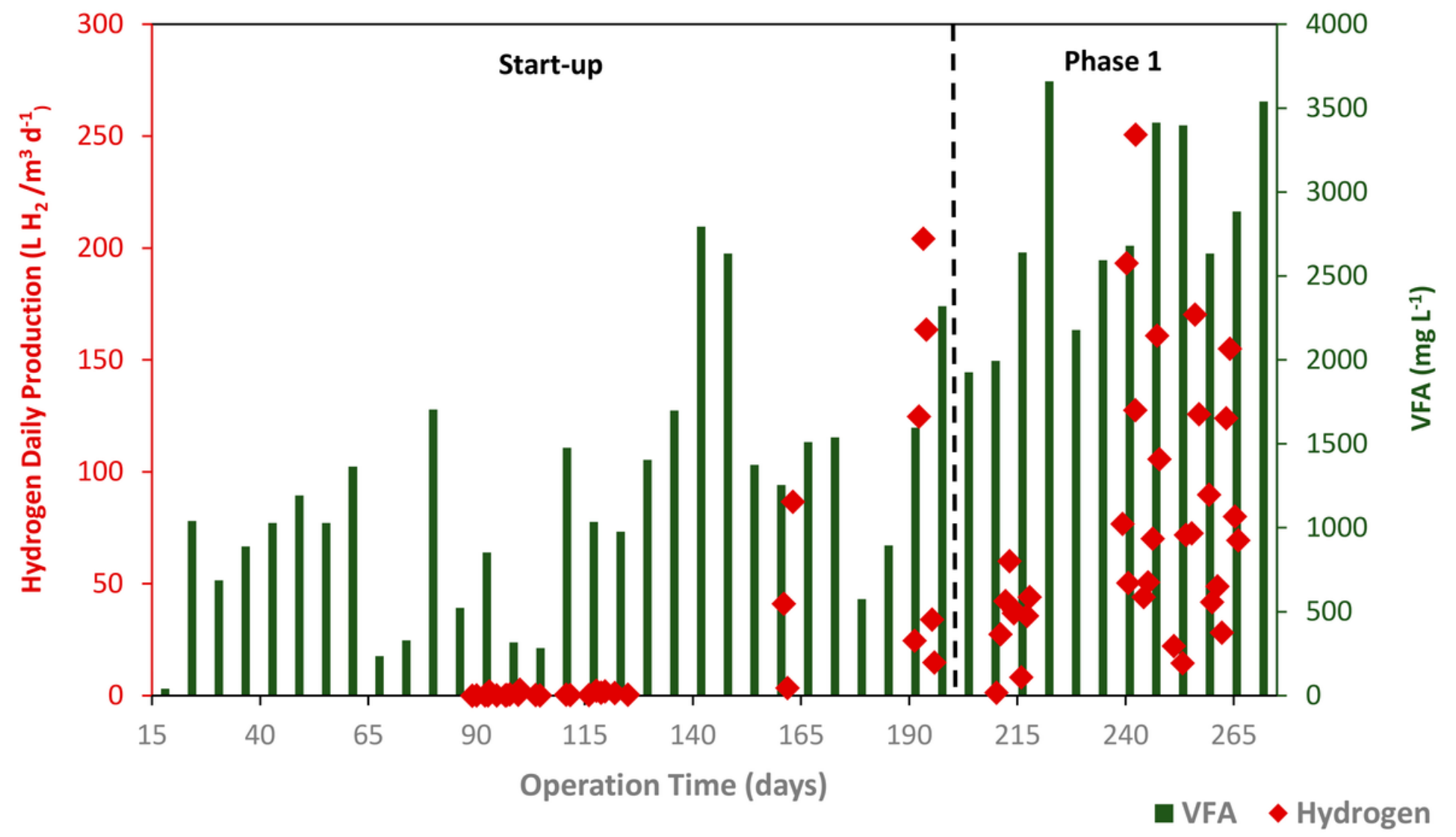

Figure 2

Daily volumetric hydrogen and volatile fatty acids (VFA) Production in the reactor R1 during the start-up and phase 1
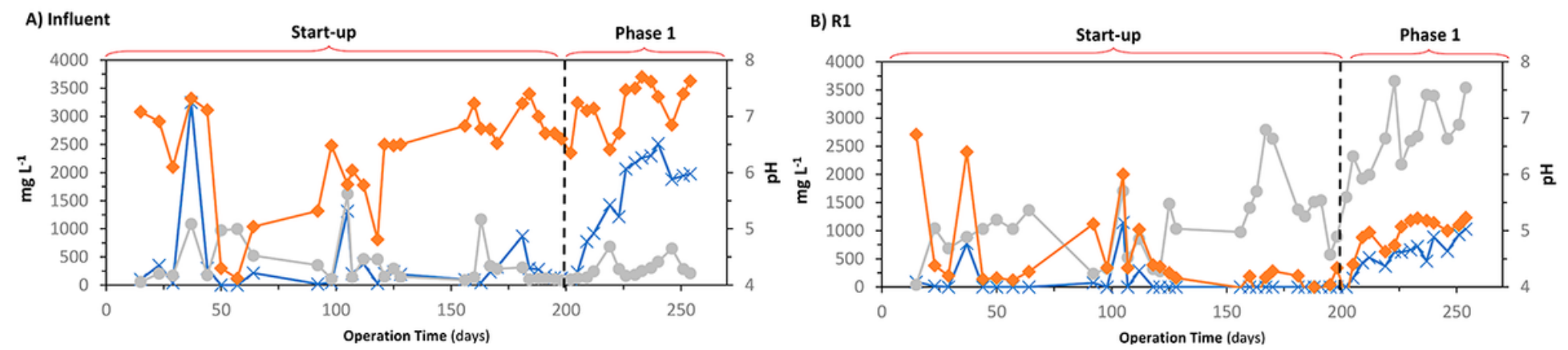

C) $\mathbf{R 2}$

D) $\mathrm{R3}$
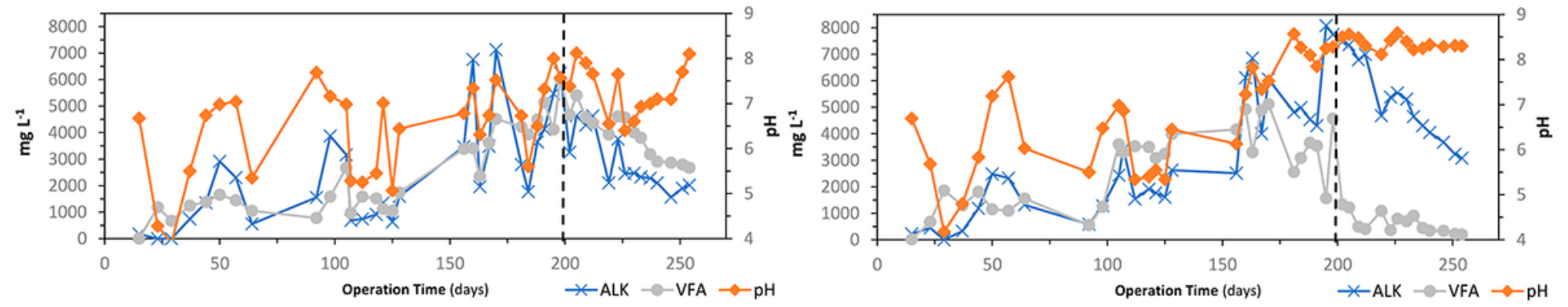
Figure 3

Alkalinity (ALK - mg CaCO3 L-1), Volatile Fatty Acids (VFA - mg L-1) and pH in the influent and effluent of the reactors $\mathrm{R} 1, \mathrm{R} 2$, and $\mathrm{R} 3$ during the start-up and phase 1
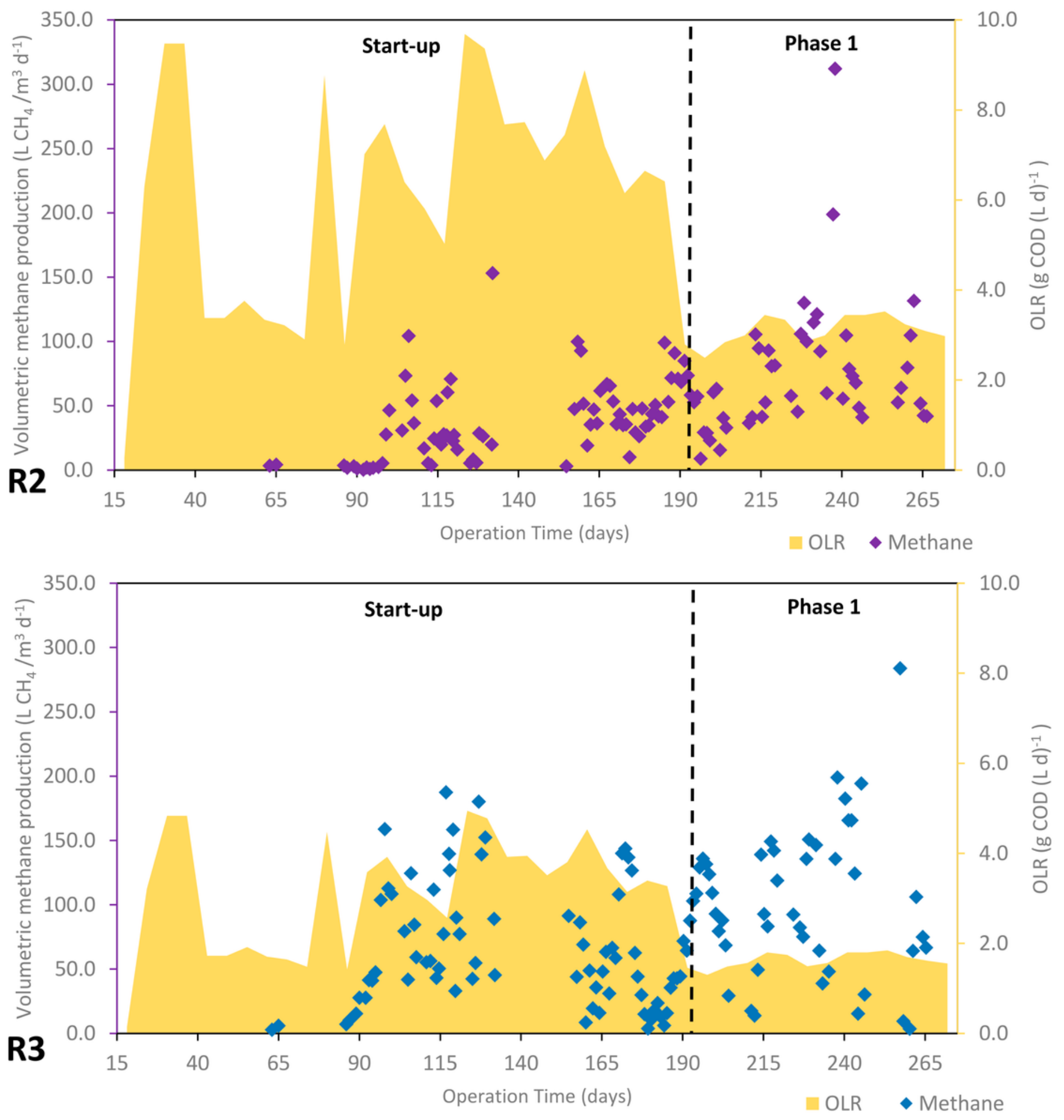

Figure 4 
Daily volumetric methane production and organic loading rate (OLR) in the reactors $\mathrm{R} 2$ and $\mathrm{R} 3$ during the start-up and phase 1
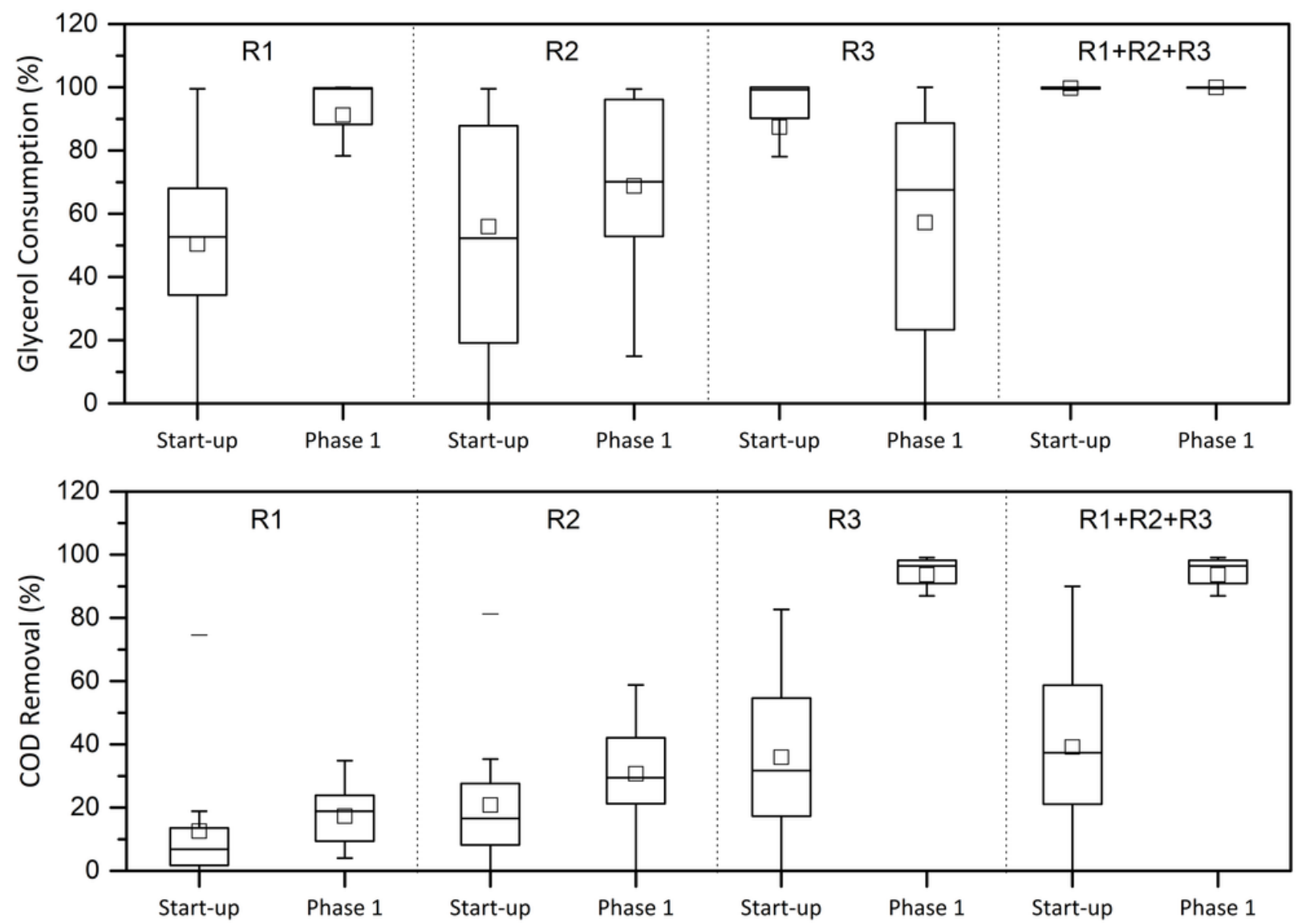

Figure 5

Glycerol consumption and COD removal in the reactors R1, R2, and R3 of the COD of their respective affluent and effluent during the start-up and phase 1
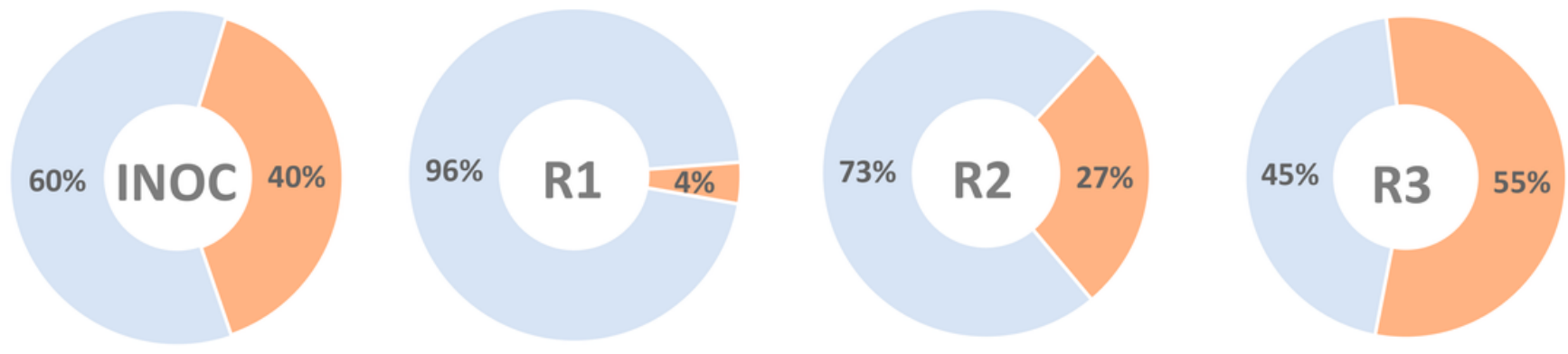

Bacteria $\approx$ Archaea 
Archaea and Bacteria Domain relative abundancy in the inoculum source and samples from R1, R2, and R3 at the end of Phase 1.

Inoculum
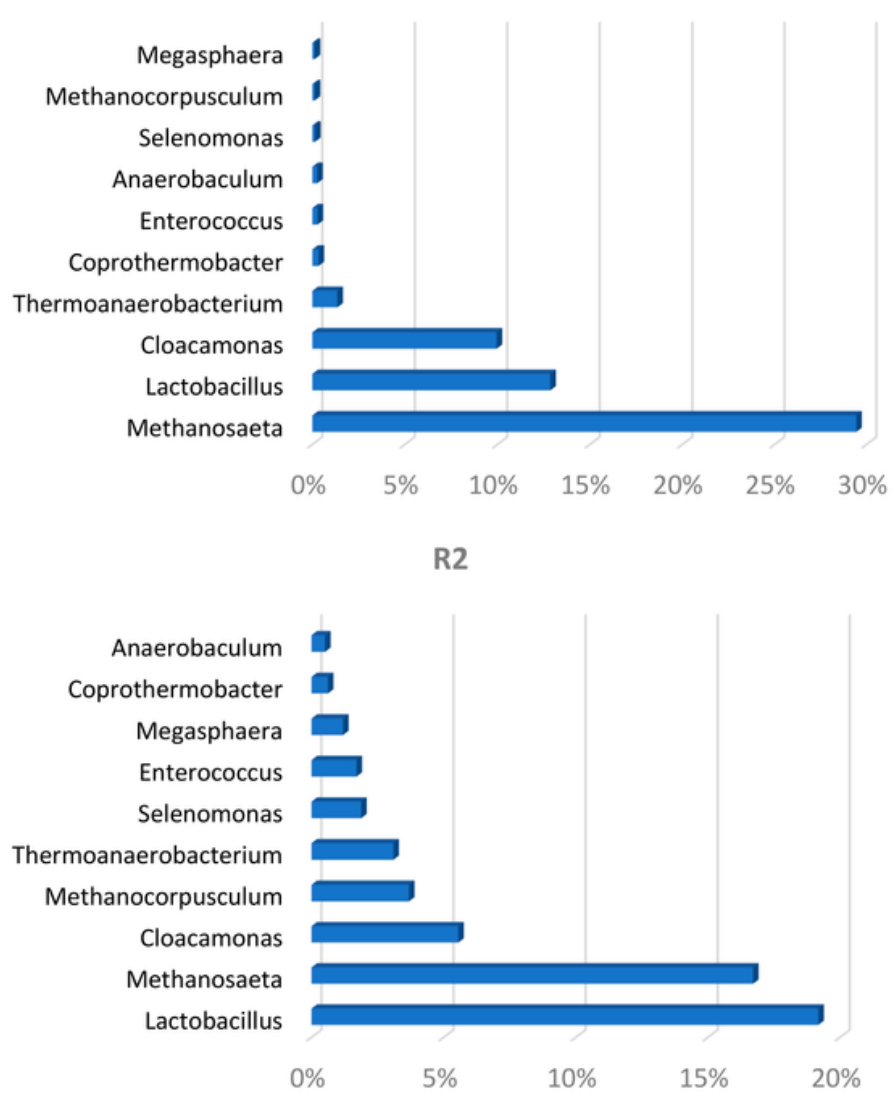

R1
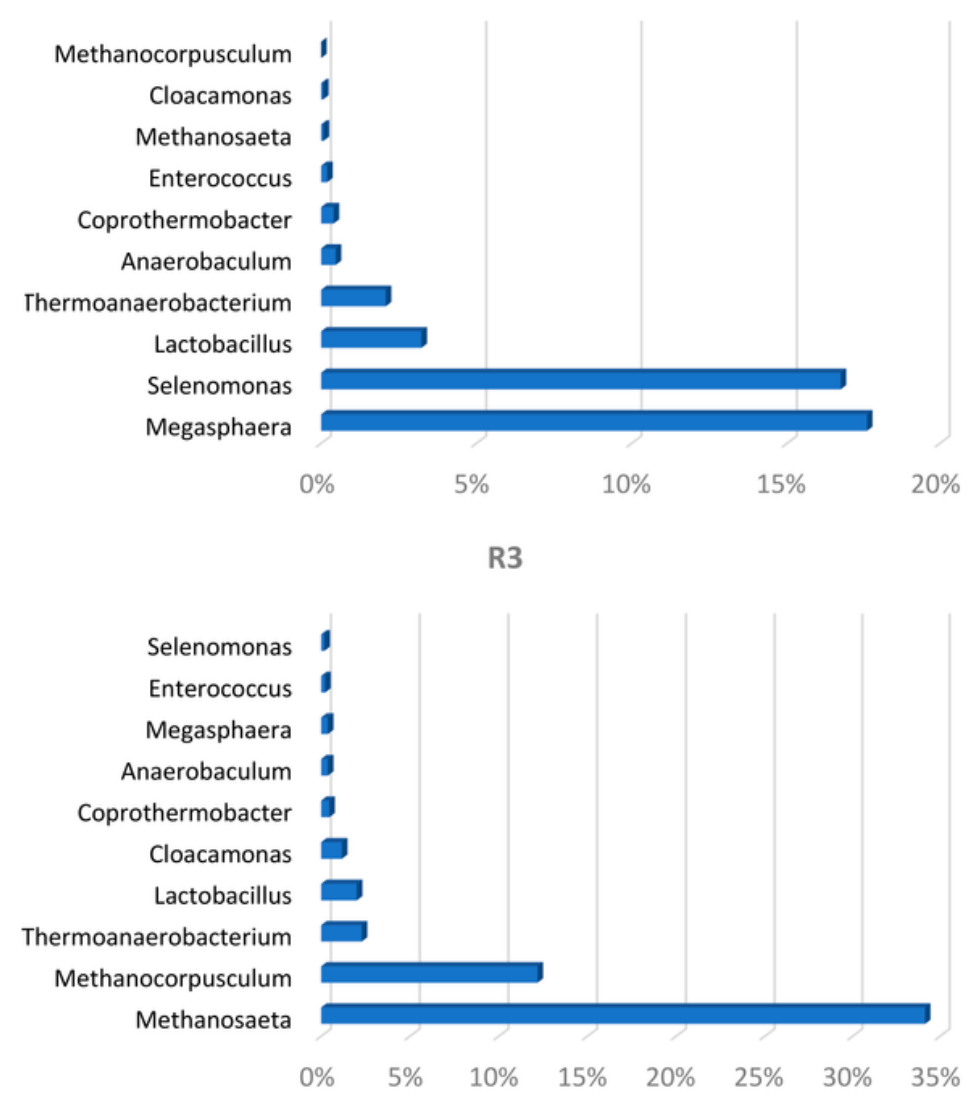

Figure 7

Distribution of relative abundance orders of Inoculum (INOC) and Reactors 1, 2, and 3 (R1, R2, and R3) at the end of Phase 1
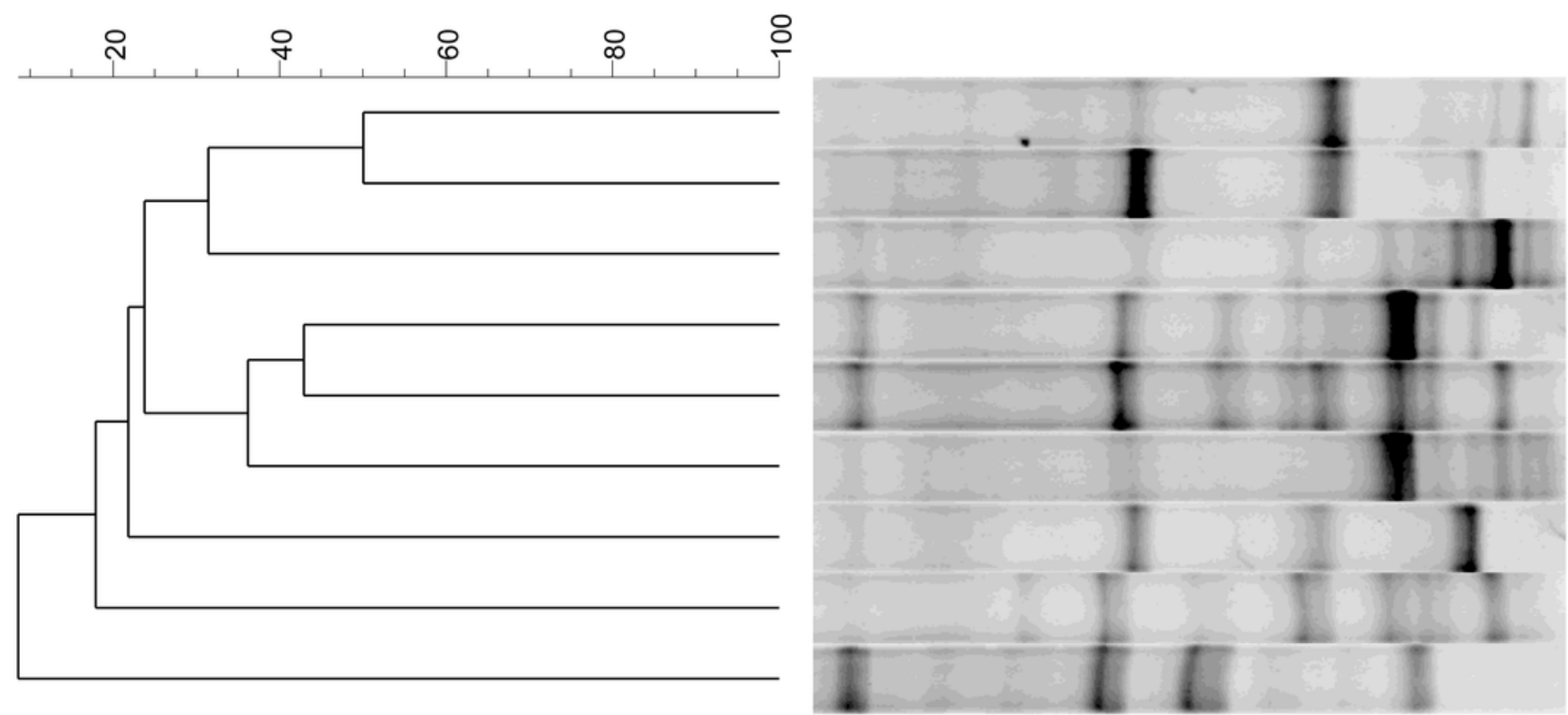

R1P2a R1P3a $\mathrm{R} 2 \mathrm{P} 2 \mathrm{a}$ R2P1a $\mathrm{R} 2 \mathrm{P} 3 \mathrm{a}$ R3P1a R1P1a R3P3a INOCa 
Figure 8

Dendrogram and similarity coefficient based on the Jaccard correlation of the samples from the 3 points (P1, P2, and P3) of each reactor (R1, R2, and R3) and inoculum (INOC) for the Bacteria domain at the end of phase 1.

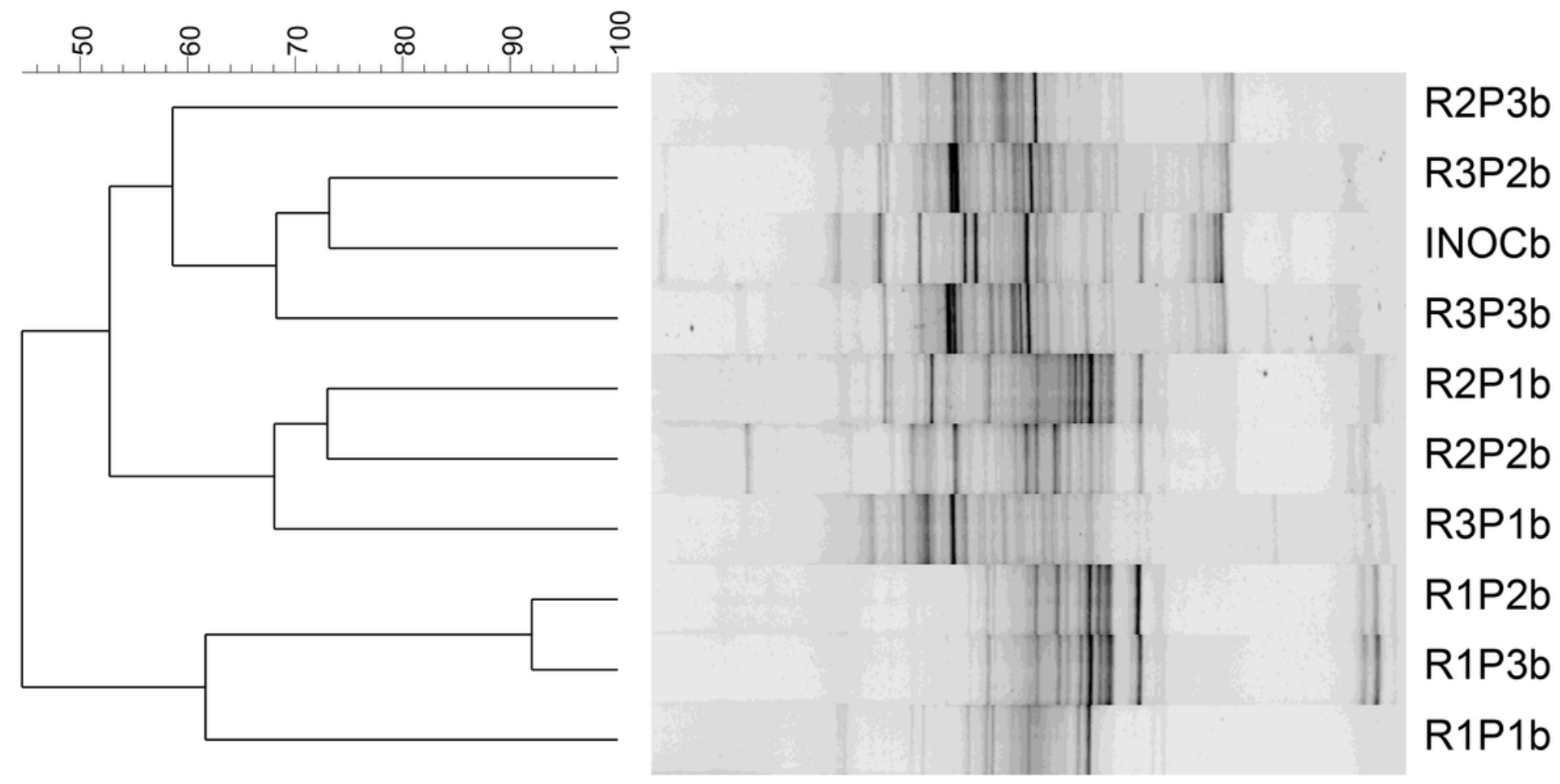

Figure 9

Dendrogram and similarity coefficient based on the Jaccard correlation of the samples from the 3 points (P1, P2, and P3) of each reactor (R1, R2, and R3) and inoculum (INOC) for the Archaea domain at the end of the phase 1 .

\section{Figure 10}

Scanning electron microscopy (SEM) of the sludge from reactors R1, R2, and R3: A) Interior of an R1 sludge granule; B) Interior of an R2 sludge granule: Methanosaeta (arrows); C) Interior of an R2 sludge granule: Methanosarcina (digitally colored); D) Interior of an R3 sludge granule: Methanosarcina (arrow)

\section{Supplementary Files}

This is a list of supplementary files associated with this preprint. Click to download.

- graphicalabstract.png 